\title{
Fiscal Year 1989 Annual Report for the Sensors Development Program
}

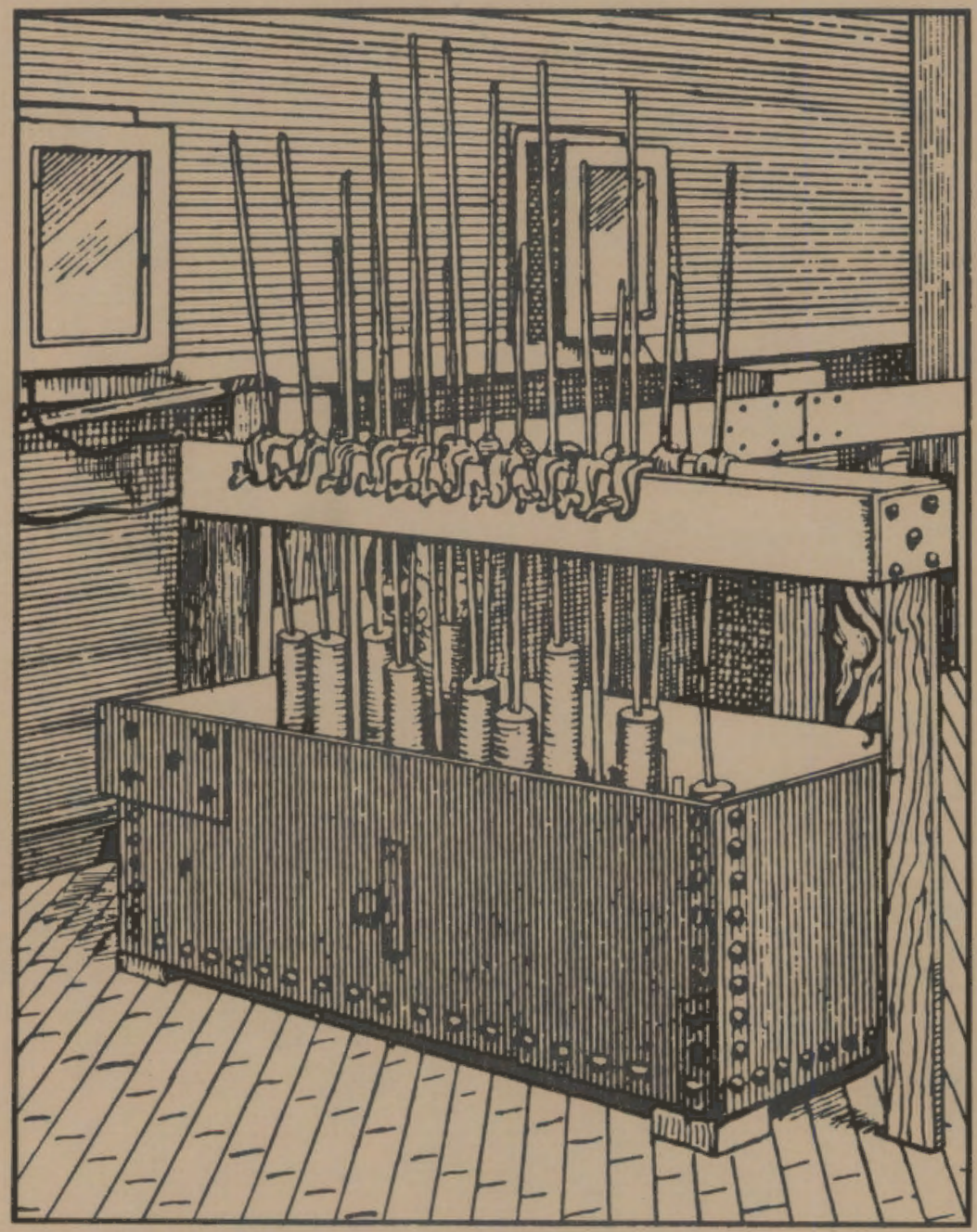

April 1990

Prepared for the U.S. Department of Energy under Contract DE-AC06-76RLO 1830

Pacific Northwest Laboratory

Operated for the U.S. Department of Energy

by Battelle Memorial Institute 


\title{
On the cover:
}

Aluminum reduction pots at the Pittsburgh Reduction

Company's (Alcoa's) plant in 1889. Adapted from a

photograph, courtesy of Alcoa.

\section{DISCLAIMER}

This report was prepared as an account of work sponsored by an agency of the United States Government. Neither the United States Government nor any agency thereof, nor Battelle Memorial Institute, nor any of their employees, makes any warranty, expressed or implied, or assumes any legal liability or responsibility for the accuracy, completeness, or usefulness of any information, apparatus, product, or process disclosed, or represents that its use would not infringe privately owned rights. Reference herein to any specific commercial product, process, or service by trade name, trademark, manufacturer, or otherwise, does not necessarily constitute or imply its endorsement, recommendation, or favoring by the United States Government of any agency thereof, or Battelle Memorial Institute. The views and opinions of authors expressed herein do not necessarily state or reflect those of the United States Government or any agency thereof.

\author{
PACIFIC NORTHWEST LABORATORY \\ operated by \\ BATTELLE MEMORIAL INSTITUTE \\ for the \\ UNITED STATES DEPARTMENT OF ENERGY \\ under Contract DE-AC06-76RLO 1830
}

\begin{abstract}
Printed in the United States of America
Available to DOE and DOE contractors from the

Office of Scientific and Technical Information, P.O. Box 62, Oak Ridge, TN 37831; prices available from (615) 576-8401. FTS 626-8401.

Available to the public from the National Technical Information Service, U.S. Department of Commerce, 5285 Port Royal Rd., Springfield, VA 22161.

NTIS Price Codes, Microfiche A01

Printed Copy
\end{abstract}

\begin{tabular}{cr}
\hline Price Code & Page Range \\
\hline A02 & $1-10$ \\
A03 & $11-50$ \\
A04 & $51-75$ \\
A05 & $76-100$ \\
A06 & $101-125$ \\
A07 & $126-150$ \\
A08 & $151-175$ \\
A09 & $176-200$ \\
A10 & $201-225$ \\
A11 & $226-250$ \\
A12 & $251-275$ \\
A13 & $276-300$ \\
A14 & $301-325$
\end{tabular}

\begin{tabular}{cc}
\hline Price Code & Page Range \\
\hline A15 & $326-350$ \\
A16 & $351-375$ \\
A17 & $376-400$ \\
A18 & $401-425$ \\
A19 & $426-450$ \\
A20 & $451-475$ \\
A21 & $476-500$ \\
A22 & $501-525$ \\
A23 & $526-550$ \\
A24 & $551-575$ \\
A25 & $576-600$ \\
A39 & $601-U p$
\end{tabular}


PNL-7309

UC -313

Inert Electrodes Program

FISCAL YEAR 1989 ANNUAL REPORT FOR THE SENSORS DEVELOPMENT PROGRAM

C. F. Windisch, Jr.

0. H. Koski

N. D. Stice

C. L. Nikias (a)

L. G. Morgan, Program Manager

April 1990

Prepared for

the U.S. Department of Energy

under Contract DE-AC06-76RLO 1830

Pacific Northwest Laboratory

Richland, Washington 99352

(a) Northeastern University Boston, Massachusetts 02115 
, 


\section{PREFACE}

C. F. Windisch, Jr., was assigned as the principal investigator to this program on April 24, 1989, replacing M. J. Danielson, who resigned from the Pacific Northwest Laboratory (PNL) on January 6, 1989.

Previous laboratory work at PNL, coupled with the analysis of digital signal analysis (DSA) data, had suggested that a DSA-based approach to monitoring and controlling aluminum reduction cell conditions might be viable. C. L. Nikias, Professor at Northeastern University, and Director of the Center for Communications and Digital Signal Processing, performed the DSA analyses. Interactions between PNL and Dr. Nikias continued in FY 1989 to determine the viability of DSA techniques for monitoring aluminum reduction cell parameters. Dr. Nikias' efforts are funded through a subcontract from PNL. He submitted two progress reports during FY 1989 (a) and visited PNL twice to discuss the results of his work.

The majority of work conducted through April 1989 was directed at developing a cermet reference anode. Despite these efforts, serious issues regarding its performance remained. Consequently, PNL recommended in a letter to the sponsor that further development of the cermet reference anode be postponed and that a more stable, albeit somewhat more fragile, reference electrode be used in future work.

The Prototype Inert Anode Test was conducted jointly by PNL and the Reynolds Metals Company in March 1989. The results of this test, including the analysis of DSA data collected during the study, will be reported separately.

A program review meeting was held in Washington, D.C., on July 20, 1989. Representatives from DOE, major aluminum companies, other contractors, and consultants were present. Details of the activities in FY 1989 for the

(a) C. L. Nikias. 1988. Advanced Signal Analysis Methods for Aluminum Smelting Data: Progress Report for December 1988. Northeastern University, Boston, Massachusetts.

C. L. Nikias. 1989. Advanced Signal Analysis Methods for Aluminum Smelting Data: Preliminary Progress Report for Period 6/18/89 to 9/30/89. Northeastern University, Boston, Massachusetts. 
Sensors Development Program were presented. DOE emphasized that the objective of the Sensors Development Program is to develop an alumina sensor that can be used on comnercial aluminum reduction cells. 


\section{SUMMARY}

Activities in support of the Sensors Development Program for FY 1989 were conducted under three major tasks: Digital Signal Analysis (DSA), Development of the Reference Anode, and Field Test of the Reference Anode.

DSA of current and voltage signals collected from PNL bench-scale laboratory cells suggest there may be correlations between certain quantification parameters derived from these data and the current density of the working anode. Although some data show a dependence on alumina concentration, additional effort is required to determine whether a correlation of DSA with this important cell operating parameter can be unequivocally shown. If successful, such a correlation would form a viable basis for a DSA-based alumina sensor.

Digital current and voltage signals collected during the Prototype Inert Anode Test gave correlations involving current density that were similar to those obtained using data from the PNL bench-scale laboratory cells. This suggests a DSA-based sensor may work in a large-scale aluminum reduction cell if it can be shown to work in a bench-scale test. In other words, there may be no serious effects on DSA data resulting from scale-up considerations.

Analog current and voltage data were generally stable throughout the Prototype Inert Anode Test and therefore did not signal the onset of the corrosion of the prototype anode that was observed in post-test analysis. This indicates that monitoring dc signals may not be a suitable approach to determining, in every case, when an inert anode is undergoing degradation during its operation.

Despite the magnitude of effort expended in FY 1989 to develop the reference anode, serious issues regarding its operation and durability remain. Problems were also encountered in trying to use the reference anode in the Prototype Inert Anode Test. Consequently, PNL recommended that further development of the reference anode be suspended. Future tests, including the Pilot Cell Test, will use an $\mathrm{AT}_{1} \mathrm{Al}_{2} \mathrm{O}_{3}$ reference electrode. The Pilot Cell Test was postponed to FY 1990 because of delays in obtaining the required materials and manufacture of the anodes from commercial vendors. 
Electrochemical impedance data collected on inert anodes in PNL benchscale laboratory cells during the evaluation of the reference anode show a dependence on current density and alumina concentration that is consistent with the formation of a resistive reaction layer. The formation of a resistive reaction layer is not the only possible mechanism for the observed results. Alternative mechanisms are being considered based on separate experimental studies. However, an alumina sensor based on the dependency of the impedance data is not expected to viable because significant hysteres is was observed in these data. 


\section{ACKNOWLEDGMENTS}

The authors wish to acknowledge the technical assistance of N. C. Davis, D. M. Strachan, R. E. Westerman, and R. E. Williford, Pacific Northwest Laboratory (PNL); the technical suggestions of $W$. E. Haupin and,R. KeTler; the programmatic support provided by $M$. J. McMonigle and the office of Industrial Programs, U.S. Department of Energy (DOE), Washington, D.C., and P. M. Pak and D. R. Segna, Richtand Operations Office, DOE. We are aTso grateful to N. E. Richards and his personnel at the Reynolds Metals Company, Sheffield, Alabama, in performing the Prototype Inert Anode Test in March 1989. 
. 
CONTENTS

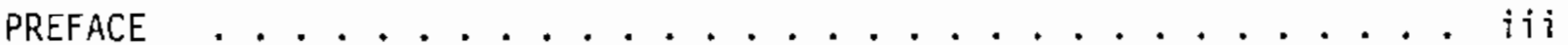

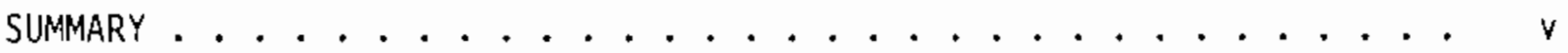

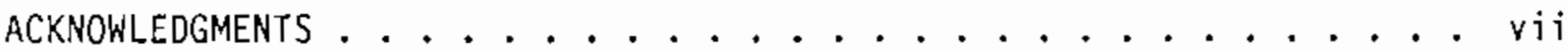

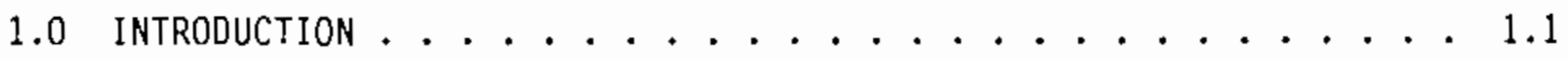

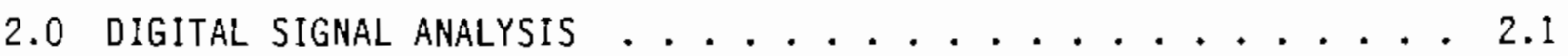

2.1 PNL BENCH-SCALE LABORATORY TESTS ............ 2.1

2.1 .1 Reports by C. L. Nikias .......... 2.1

2.1.2 Experimental Setup ................ 2.3

2.1 .3 Results ............... 2.5

2.1 .4 Conclusions .......................... 2.14

2.2 PROTOTYPE INERT ANODE TEST . . . . . . . . . . . 2.14

2.2.1 Experimental Setup .......................

2.2 .2 Results ................ . . 2.18

2.2 .3 Conclusions . . . . . . . . . . . . 2.21

3.0 DEVElOPMENT OF THE REFERENCE ANODE . . . . . . . . . . 3.1

3.1 PROTOTYPE INERT ANODE TEST. . . . . . . . . . . 3.2

3.2 RECOMMENDATION CONCERNING THE REFERENCE ANODE . . . . . . 3.4

3.3 EleCtROChEMiCAL IMPEDANCE MEASUREMENTS . . . . . . 3.5

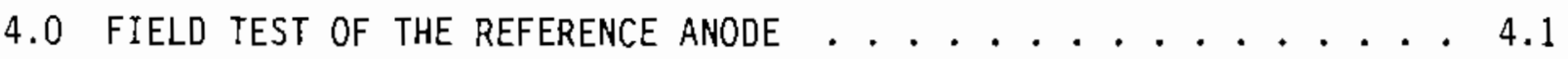

4.1 STATUS OF THE FIELD TEST. . . . . . . . . . . 4.1

4.2 PLAN FOR FIELD TEST . . . . . . . . . . . . 4.1

5.0 CONCLUSIONS AND FUTURE DIRECTIONS . . . . . . . . . 5.1

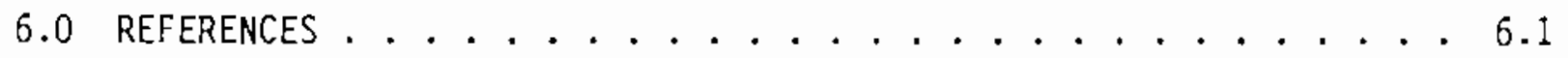

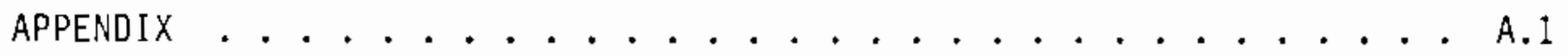




\section{FIGURES}

2.1 Apparatus for PNL Bench-Scale Laboratory DSA Tests . . . . . 2.4

2.2 Examples of DSA Plots . . . . . . . . . . . . 2.8

2.3 Parameter $\mathrm{R}(0)$ : Comparison for Prototype Inert Anode Data $\mathrm{B}$ Low-Passed Voltage Signals.............. 2. 2. . . . .

2.4 Parameter $R(0)$ : Comparison for Prototype Inert Anode Data $C$ Low-Passed Voltage Signals ............. 2.10

2.5 Parameter $\mathrm{P}(1) / \mathrm{R}(0)$ : Comparison for Prototype Inert Anode Data B Low-Passed Voltage Signals . . . . . . . . . . . . . . 2.11

2.6 Parameter $P(1) / R(0)$ : Comparison for Prototype Inert Anode Data C Low-Passed Voltage Signals . . . . . . . . . . . 2.11

2.7 Parameter $\mathrm{R}(\mathrm{O})$ : Original Current Signals Showing Effect of Alumina Concentration .............. 2.12

2.8 Parameter $R(0)$ : Low-Passed Current Signals Showing Effect of Alumina Concentration . . . . . . . . . . . 2.12

2.9 Sensor and Instrument Assembly for Digital Signal Monitoring in the Prototype Inert Anode Test . . . . . . . . . 2.16

2.10 Strip Chart Recorder Arrangement for the Prototype Inert Anode Test ................. 2.19

3.1 Corrosion of Reference Anode . . . . . . . . . . . . 3.2

3.2 Resistance versus Current Density with Percent Alumina Saturation Dependence ................ 3.6

3.3 Reproducibility of Anode Resistance for $80 \%$ and $100 \%$

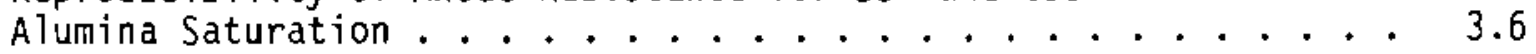

4.1 Pilot Cell Test Sensor Configuration .......... 4.2

\section{$\underline{\text { TABLES }}$}

2.1 Data Files for DSA, PNL Laboratory Tests . . . . . . . . . 2.6

2.2 Description of Conditions at Data Collection Times for Prototype Inert Anode Test ............. 2.17 


\subsection{INTRODUCTION}

The Sensors Development Program is conducted at the Pacific Northwest Laboratory (PNL) for the U.S. Department of Energy (DOE), Office of Industria] Programs (OIP). The work is being performed in conjunction with the Inert Electrodes Program at PNL. The objectives of the Sensors Development Program are to 1) investigate and develop methods of process monitoring/control for operating electrolytic cells and 2) determine safe operating conditions for the inert anodes. The majority of work in FY 1989 involved 1) evaluating Digital

Signal Analysis (DSA) methods to monjtor inert anode operation and to determine alumina concentration in both PNL bench-scale laboratory celis and the Prototype Inert Anode Test and 2) developing the reference anode against which inert anode voltage signals could be measured by the DSA-based or other methods. These efforts were organized and conducted as indicated in the following brief task descriptions.

Task 1: Digital Signal Analysis. The objective of this task is to use DSA methods to determine whether any useful correlations exist between cell operating conditions and various DSA-derived quantification parameters calculated using current and voltage signals obtained from both laboratory and field aluminum reduction cells. The jdea is that, if appropriate correlations can be found, the quantification parameters might be used to monitor and, consequently, help control these cell operating conditions in comanercial reduction cells. A subcontract was issued to Dr. C. L. Nikias, Professor at Northeastern University, Boston, Massachusetts, and Director of the Center for Communications and Signal Processing, to assist in developing DSA-based methods by analysis of data from PNL bench-scale laboratory tests and field tests of the inert anode. In FY 1989, Or. Nikias completed studies on PNL bench-scale laboratory data obtained for various current densities and alumina concentrations, and on data collected during the Prototype Inert Anode Test. Task 2: Development of the Reference Anode. The purpose of this task was to continue the development of the cermet reference anode that was started in FY 1988 and to get the reference anode to a development state appropriate for employment in the Pilot Cell Test to be conducted at the Reynolds Metals Company, Sheffield, Alabama. During FY 1989, the reference anode was evaluated 
in numerous PNL bench-scale laboratory tests and in the Prototype Inert Anode Test conducted at Reynolds Metals Company, Sheffield, Alabama, in March 1989. Based on the results of this work, PNL recommends that further efforts to develop a cermet reference anode be deferred.

Task 3: Field Test of the Reference Anode. The objective of this task was to evaluate the cermet reference anode in the Pilot Cell Test and to use the reference anode and various sensor approaches to monitor the operation of the inert anodes during the test. A data acquisition system was purchased for this purpose and evaluated in the PNL laboratory. The Pilot Cell Test was postponed to FY 1990; hence, this task will continue in FY 1990 in accordance with the Pilot Cell Test schedule.

This Sensors Development Program annual report highlights the major technical accomplishments of FY 1989. The accomplishments are presented according to each task. A Conclusions/Future Directions section is provided to document the approach proposed to reach closure on the overall objectives of the Sensors Development Program. 


\subsection{DIGITAL SIGNAL ANALYSIS}

This work investigated the analysis of aluminum smelting data, specificalTy cell current and voltage signals, using advanced DSA methods based on both linear and nonlinear signal modeling techniques. The principal objective was to identify and measure the effect of DSA-derived signal quantification parameters that are sensitive to changes in the values of electrochemical parameters such as alumina concentration, current density, bath ratio, and temperature. The quantification parameters may be useful as noninvasive process monitoring and control methods capable of providing real-time information on aluminum production cell conditions. This, in turn, will assist in maximizing the efficiency of commercial aluminum smelting operations.

The approach taken in this work has been for PNL to collect digital current and voltage signal data from PNL bench-scale laboratory tests and field tests, including the Prototype Inert Anode Test and the Pilot Cell Test, and submit these data to Dr. C. L. Nikias for analysis. Dr. Nikias, an expert in the field of DSA, has evaluated a number of DSA approaches to determine techniques that may give a useful correlation between the quantification parameters calculated from the digital signals and the various cell operating conditions, especially alumina concentration.

\subsection{PNL BENCH-SCALE LABORATORY TESTS}

Short-term bench-scale experiments were performed at PNL to obtain the data necessary to establish whether correlations exist between the DSA-derived quantification parameters and cell operating conditions. PNL bench-scale experiments are being used because their operating conditions, specifically current density and bath composition, can be adjusted more easily and controlled more precisely than large-scale cells.

\subsubsection{Reports by Dr. C. L. Nikias}

Two progress reports submitted by Dr. Nikias during FY 1989 present the results of his analyses of the PNL-obtained DSA-type data. The first progress 
report (a) covered results obtained from PNL bench-scale laboratory test data obtained in FY 1988. These data included current, voltage, and acoustic signals collected under various cell operating conditions, specifically alumina concentration, bath ratio, controlling current density, and temperature. Although the analys is suggested certain correlations between selected quantification parameters and cell operating conditions, especially bath ratio, the analysis gave no definitive conclusions primarily because adequate statistical analyses could not be performed. An adequate number of data sets were not available to establish accurate relationships with statistical confidence. Recent work has shown that most of the meaningful correlations between quantification parameters and cell operating conditions occur using lower frequency signals $(<100 \mathrm{~Hz})$. Most of the focus in the initial report involved searching for the less-likely correlations with high frequency signals. Later work used various band pass methods to isolate the lower frequency signals; subsequent analysis of these signals has given better correlation results.

The second report(b) by Dr. Nikias was submitted to PNL on September 30, 1989. In this report, Dr. Nikias detailed the results of his analysis of digital current and voltage signals collected in PNL bench-scale laboratory tests during FY 1989.

These results are discussed below. The report also covers the analys is of the Prototype Inert Anode Test data (discussed in Section 2.2). Dr. Nikias also visited PNL on November 3, 1989, to discuss these results with PNL staff. Based on these discussions, he reexamined some of the Prototype Inert Anode Test data. The results of the reanalys is were submitted to PNL on November 7 , 1989 (discussed in Section 2.2).

(a) Nikias, C. L. 1988. Advanced Signal Analysis Methods for Aluminum Smelting Data: Progress Report for December 1988, Northeastern University, Boston, Massachusetts.

(b) Nikias, C. L. 1989. Advanced Signal Analysis Methods for Aluminum Smelting Data: Preliminary Progress Report for Period June 18, 1989 to September 30, 1989, Northeastern University, Boston, Massachusetts. 


\subsubsection{Experimental Setup}

The PNL bench-scale laboratory data that were analyzed and subsequently reported in the September 30,1989, report by Dr. Nikias were collected using the experimental setup shown in Figure 2.1.

An IBM AT was used with the Rapid Systems, Inc., R360 Real Time Spectrum Analyzer software for data acquisition, control, and storage. Signals were input to the AT using the spectrum analyzer, which consist of a digital signal processing interface board and the $4 \times 4$ digital oscilloscope peripheral. Inputs to the $4 \times 4$ were current and voltage signals taken from the rear of a Solartron $1286^{\circ}$ electrochemical interface that was used as a galvanostat (under current control) in these experiments.

The electrochemical cell was exactly the same as used in previous sensors development work at PNL; it consisted of a graphite crucible that served as the cathode and a BN-sheathed cermet electrode as the anode. The exposed surface area of the anode was $1 \mathrm{~cm}^{2}$. The bath was prepared by mixing appropriate amounts of reagent-grade materials to give a bath ratio equal to $1.15,5.5 \%$ (by weight) $\mathrm{CaF}_{2}, 1.0 \% \mathrm{MgF}_{2}$, and the alumina concentration at the desired value. Alumina concentrations in this report are given as a percent of saturation, which for these conditions is approximately $6.0 \%$ by weight. A temperature controller/furnace/thermocouple was used to control the bath temperature at $983^{\circ} \mathrm{C}$. Bath ratio and temperature were effectively constant throughout these short-term experiments. In a given test, the anode was inserted once the bath had become molten, the temperature was allowed to reequilibrate, then the anode was polarized galvanostatically to give the desired current density. Current and voltage signals were subsequently collected from the electrochemical interface using the spectrum analyzer.

- AT is a registered tradename of International Business Machines, Armonk, New York.

D R300 and R360 Real Time Spectrum Analyzer is a registered tradename of Rapid Systems, Inc., Seattle, Washington.

- Solartron 1286 is a tradename of Solartron Instruments, Farmborough, Hampshire, England. 


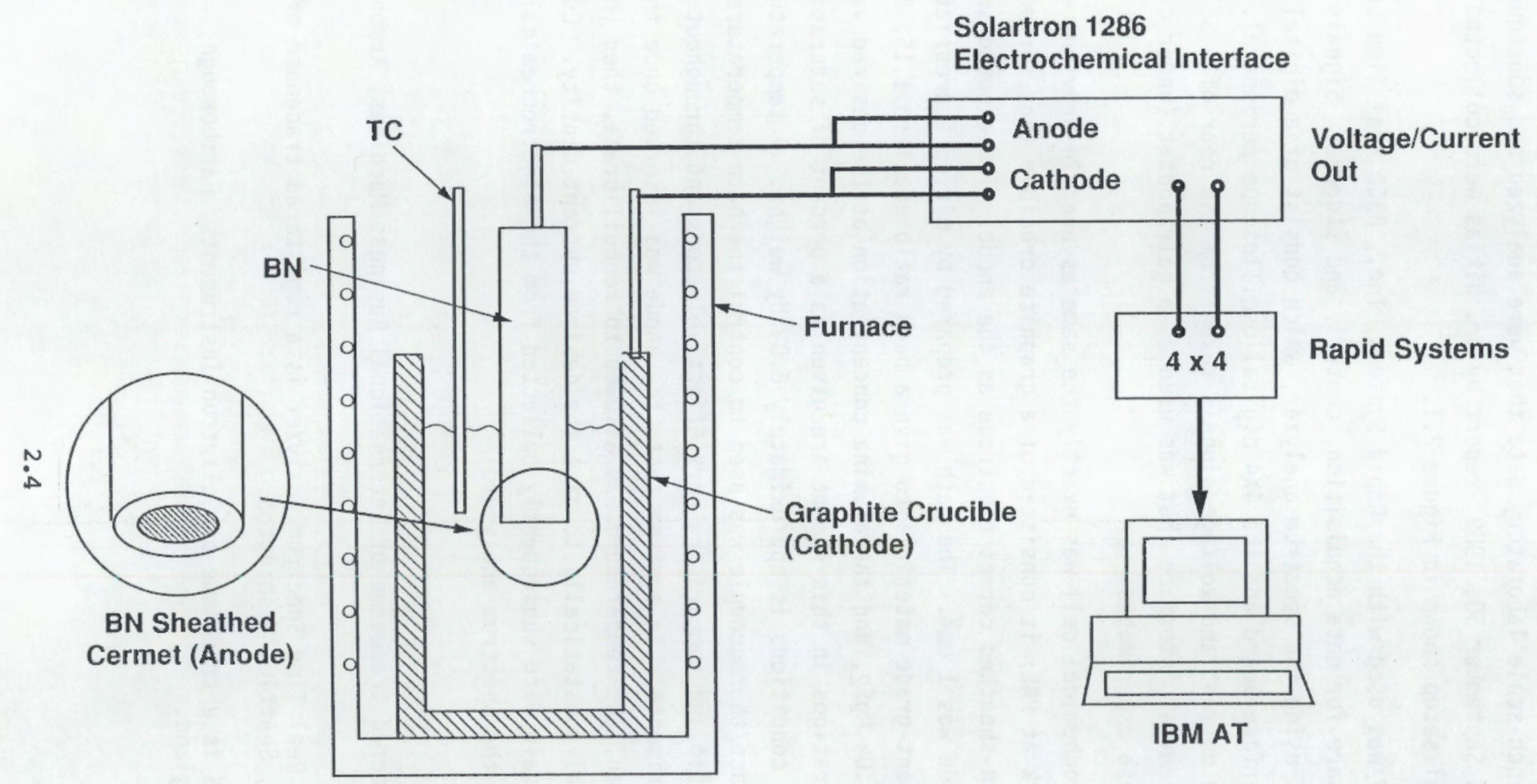

38912079.7

FIGURE 2.1. Apparatus for PNL Bench-Scale Laboratory DSA Tests 
Each set of data obtained was at a given current density and alumina concentration and consisted of 2048 sequential signals collected over a period of $0.4 \mathrm{~s}$ ( $5 \mathrm{kHz}$ sampling frequency). The procedure was repeated for anodes operating at current densities equal to $0.1,0.5,1.0,1.5$, and $2.0 \mathrm{~A} / \mathrm{cm}^{2}$ current density, and alumina concentrations at $10 \%, 20 \%, 40 \%, 60 \%$, and $80 \%$ of saturation.

The digital signals were stored as files on 1.2 MB floppy disks. A list of these files and the representative current densities and alumina concentrations (expressed as percent of saturation) is given in Table 2.1. The files with modifiers DT1 and DT2 contained the current and voltage signals, respectively, for each set of cell conditions.

\subsubsection{Results}

Four DSA techniques were used to analyze current and voltage signals obtained from bench-scale PNL laboratory test cells: the Welch fast Fourier transform (FFT)-based method, the Yule-Walker (YW) autoregression (AR) method, the magnitude-squared coherence (MSC) method, and nonlinear second-order Volterra modeling. Descriptions of these techniques are given in the Appendix, which is excerpted from Dr. Nikias' September 30, 1989, report. Some examples of the types of plots derived from these approaches are shown in Figure 2.2.

Among the set of ad hoc quantification parameters that have been identified from the DSA methods used, the ones that show the best correlation with cell operating parameters appear to be $R(0)$, the total power of the signals, and $P(1) / R(0)$, which is related to the shape of the signals. Both of these quantification parameters obtained from low-passed $(<25 \mathrm{~Hz})$ voltage signals appear to show some correlation with working anode current density. The correlations were observed over a range of alumina concentrations.

The correlations observed for $R(0)$ and $P(1) / R(0)$ for low-passed voltage signals were as follows:

- $R(0)$ decreased slightly when the current density changed from 0.1 to 0.5 $A / \mathrm{cm}^{2}$ and then increased with current density above $0.5 \mathrm{~A} / \mathrm{cm}^{2}$. The most dramatic increase occurred when the current density changed from 1.5 to $2.0 \mathrm{~A} / \mathrm{cm}^{2}$.

- $P(1) / R(0)$ increased slightly when the current density changed from 0.1 to $0.5 \mathrm{~A} / \mathrm{cm}^{2}$ and then decreased when current density exceeded $0.5 \mathrm{~A} / \mathrm{cm}^{2}$. 


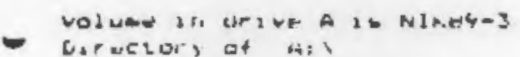

- Cumbiratis c0!1 NI1.2-1bi. Lis NIt:- - doi, Lil? NI1.:-1 bu OrE

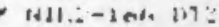
NII:-Ien CI4 Ni1:-10t IITIS

- NIt.- - Leki DTd N11:--1 of, DT: NIV:2-let. DTS

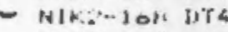
N1S:-1EL: DTR (d) -

- N1K:Z-1OCLT: NII:Z-I bI: DT? NIY:- -1 \&C DTA

- NII.2-1 bl |ा NIH,-10L UT! IAII:- $-10 D$ DR:

- N16:-IBD DT: NII: -100114 NIK2-IOE DTO

- NIIE-I bE UTJ N11:2-16E DT: NIV:2-10E DTS

- NII:Z-ILE DT4 NII:- I of DIC NIV::- 1 oF $D I:$

- NII:-IDF DI: NII:2-10F DT: N1I:2-1 OF UIA

- NIK-16G DTU NIIE-16G DTI N1K:Z-1OG DT2

- NIK:-IGE LT3 NIK̈:-16G DTA NII:2-1 OH DTO

- INIKE-IGH DTI NI $1: 2-1 \angle H$ LT: NIN2-1OH DTJ

- NIK2-16H DTA NIK:-1DI DTO NIIZ-101 DTI

- NIIS2-1bl DT2 NIK2-1 Ol DTS NIH:Z-1 I I DT 4

- Nalie-zos lito NII:- 10.2 DII NII:-102 DT2

- N11:2-16J LT3 NIKE-1OJ DT4 NII:-16K Dru

- NINz-1ol. Di1 Nil:-isl: DT2 NII:- 2 GK DTE

- NII:Z-16K DIA NIIS-2 OL ETO NIH:2-1OL DT 1

- NIKE-IOL CTE NIIZZ-I GL CTS N11:2-1 OL DTA

- NIKISH DTC NIK: OM [II N11.10M DTE

- NItEJoM DTZ NIIIJE DTA NIY:-1ON UTA

- idi:-jolv vTI NIH:-1 bN UT:NIKE-ION LTE

- Nil:-1 olv UTA NII:-ISF DTO N11.2-1 or WT

- WII:-10F UTZ NII:-1 GF DTS NIK=-1 \&P DTA

- NIKZ-IBU DTO NIK2-160 DTI NIKE-160 DT2

- NIR2-160 DTE NIF:2-160 DT4

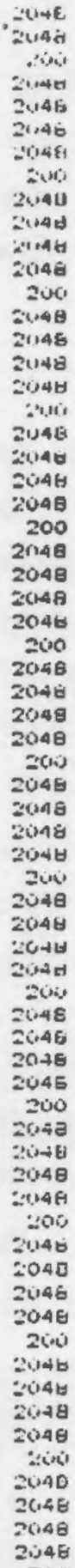

2048

1-10-14

$\because-10-8 \%$

:-10-64

$\therefore-1 b-49$

is-1 sलnप

$2-10-64$

$2-10.84$

and $\cdots$

$2-10-144$

$\because-16-t^{2}$

2-10-119

$2-10-84$

$\therefore-16-44$

$:-16,-4 y$

2-10-64

2-16-89

$2-10-69$

$2-16-89$

$2-16-89$

$2-16-89$

2-1 d- 6 ?

2-1 b-

2-16-84

2-10-69

$2-16-94$

2-16-89

$2-1 b-89$

$2-1 b-89$

$x-10-94$

2-10-

$2-16-84$

z-1b-a9

2-10-64

2-1

:-10-44

$2-16-99$

$:-10-44$

$=-10-69$

:-1a-E4

$2-10-34$

:-1<-49

$2-16-39$

$\because-16-64$

$2-20-89$

:-1a-H4

$2-20-84$

$2-1 c-199$

20) $0-y 4$

a-1e-84

$\therefore-10-49$

2-10-E4

2-10-5्र

z-10-by

- $-10-$ th

2-10-44

$\because-10-8>$

2-16-tey

2-10-년

$=-1 e-44$

$2-1<-94$

$2-10-89$

$-10-44$

2-16-89

$z-1 b-\theta 4$

:-10-84

2-1b-t的

$2-10-89$
$-1 a-1.5$ 12:- 104

$\because-1 t-t^{4}, \quad 12: 4 \mathrm{ml}$

$:-10-34 \quad 1: 2000$

$\because-1 \mathrm{n-t} 4 \mathrm{Y}$ 1::471

$z-1 s-69 \quad 12 z 4 ? 0$

2-10-64 1-14ik

z-1b-64 12:4\%

$\because=1 t-107 \quad 1: 14 \%$

2-16-44 1:2445

$:-10-64 \quad 1: z 4 y_{1}$

23- $10-614$

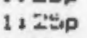

1: 25

s.7p

$1: 27 p$

$1:=7 p$

$2: 27$

$2: 2 \forall \forall p$

$3: 26 \mathrm{p}$

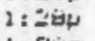

1 : 2us

$1:$ :

1: : $27 p$

1: $1: 09$

$1: 24 p$

$2: 2915$

$1:=1 \mathrm{r}$

$1: 310$

$1: 32 \omega$

$1:=1 p$
$1: 32 p$

$3: 0.79$

$z: 045$

Z: isp

3:145

3 is

I: 215

$\overline{Z: 120}$

$\geq 110$

3:110

3: 120

3: 120

$\because 1=p$

:

$z=12 p$

$\therefore: 2=0$

i: $1=0$

: 130

$\therefore 1=1$

$3: 12 p$

ज小

: 1 :

3: 1 ए

$\overline{5}:: 50$

3: $24 p$

Current Density

$0.5 \mathrm{~A}$

10

0.1

10

1.0

10

1.5

10

2.0

10

0.5

20 
TABLE 2.1. (contd)

( 8 of Saturation)

Current Density

$\mathrm{Al}_{2} \mathrm{O}_{3}$

\begin{tabular}{|c|c|c|c|}
\hline & 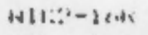 & t). & zar \\
\hline & iv $11 . .-1 \mathrm{~cm}$ & LI! & $\because 14+4$ \\
\hline & (N1):2-1 on & $01:$ & 20.46 \\
\hline & NIH::-1EF & $171:$ & $\therefore$ tolsts \\
\hline \multirow[t]{3}{*}{ 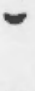 } & IdIS.Z-joh & |山 & 20.060 \\
\hline & NI1::-165 & DI0 & $\because n$, \\
\hline & Nil:::-1ats & {$[, T 1$} & $20.4+3$ \\
\hline \multirow[t]{3}{*}{ 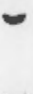 } & $1+11: 2-100$ & ni: & 2eDAHA \\
\hline & (N1):z-105 & DTs & 20,040 \\
\hline & HIRZL J a: & $\mathrm{DI} 4$ & $\because$ WAF \\
\hline \multirow[t]{3}{*}{ ש } & $\mid+11.2-101$ & 010 & $\therefore \omega$ \\
\hline & NIH:L- $10 \mathrm{~T}$ & DPI & $204 \mathrm{~A}$ \\
\hline & $N 11:-b=T$ & Dr:? & $\approx 0491$ \\
\hline \multirow[t]{3}{*}{ 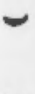 } & NII:Z-16! & 1213 & $\because 016$ \\
\hline & NIK:-101 & I T i & $=\dot{0} 4 \mathrm{G}$ \\
\hline & Nik.-1 ou & Dro & $2 \sin$ \\
\hline & N11::-1 Su & CT1 & 2046 \\
\hline & $N \mid k 2-16 U$ & DT: & $\because 140$ d \\
\hline & mit:-ion & DTZ & 2,040 \\
\hline \multirow[t]{3}{*}{, } & NII:Z-1 ab & P) & $\because \cos \theta$ \\
\hline & NIH:Z:-10V & טTO & 200 \\
\hline & NII:--16V & bri & $2134 \dot{\theta}$ \\
\hline \multirow[t]{3}{*}{ 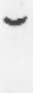 } & NIKE-ISV & DT: & $20(146$ \\
\hline & INII:S-10V & טT3 & $z(14 t)$ \\
\hline & NN1K:Z-10V & DTA & 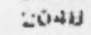 \\
\hline & N1:Z2-1 & wro & 201,1 \\
\hline & NIK:-1OW & Dו & 2044 \\
\hline & NIKI-1 oW & DTE & $\because 240$ \\
\hline & NII:2-1 bW & CTS & 2048 \\
\hline & NIK2-10H & D14 & 2046 \\
\hline & NII:2-1 $6 x$ & DTO & 200 \\
\hline \multirow[t]{3}{*}{ 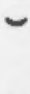 } & NIKL-16x & DT 1 & 2048 \\
\hline & NIKZ=16X & DTZ & 2046 \\
\hline & NIKZ- J6X & DTS & 2040 \\
\hline & N1t:2-16x & DrA & 2048 \\
\hline & NIKZ-1EY & DTO & 200 \\
\hline & NIHE- $16 Y$ & OT 1 & 20446 \\
\hline & NII: $=-16 Y$ & LT2 & 2048 \\
\hline & IN $1:=2$ - 1 or & DTJ & $204 \mathrm{E}$ \\
\hline & NIY:2-10Y & UTA & $\because 0.48$ \\
\hline & NIr:Z-1OZ & DTa & 200 \\
\hline & NIK:2-1O2 & DT 1 & 2048 \\
\hline & faIt:5-70, & CT2 & 2046 \\
\hline & N1K:2-1b7 & DrJ & 2048 \\
\hline & |xII:Z-1૯Z & Dra & 20140 \\
\hline
\end{tabular}

$\therefore 11 .+4$

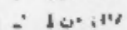

2-10-uप

$\because-j 0-40$

- in-aic

$\therefore=10-4$,

$-1 L-H^{4}$

$\therefore-1 n-A 4$

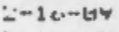

$\because-1 t_{1}-114$

$\therefore-10-4,4$

$\because-10-6 \%$

$:-1 m-4 A$

$\therefore-10-64$

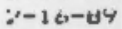

$\because-10-84$

2-1 de-64

:16-164

$2-16-144$

$7-1 n-639$

2-10-69

$2-10-89$

$20-10-89$

$z-10-|x\rangle$

:-1n-4a

$\because-10-49$

:-10-49

$2-1 n-x 9$

$2-10-64$

2-1 $16-44$

2-1b-

:-10-69

2-10-04

2-16- 39

$2-1<-84$

2-1 $19-84$

$z-16-49$

2-16-69

$2-10-94$

:-10-44

2-16-49

$2-16-84$

z-10-44

$2-16-84$
$3-10-59$

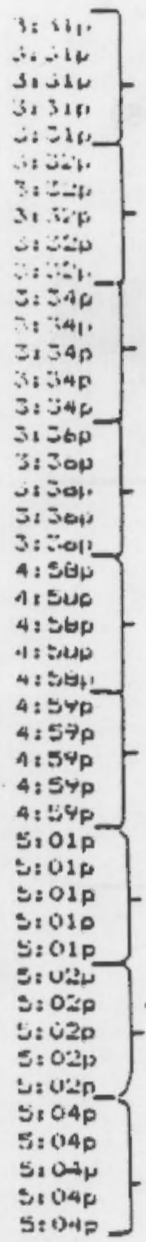

0.1

60

1.0

60

1.5

60

2.0

60

0.5

80

0.1

80

1.0

80

1.5

80

2.0

80 


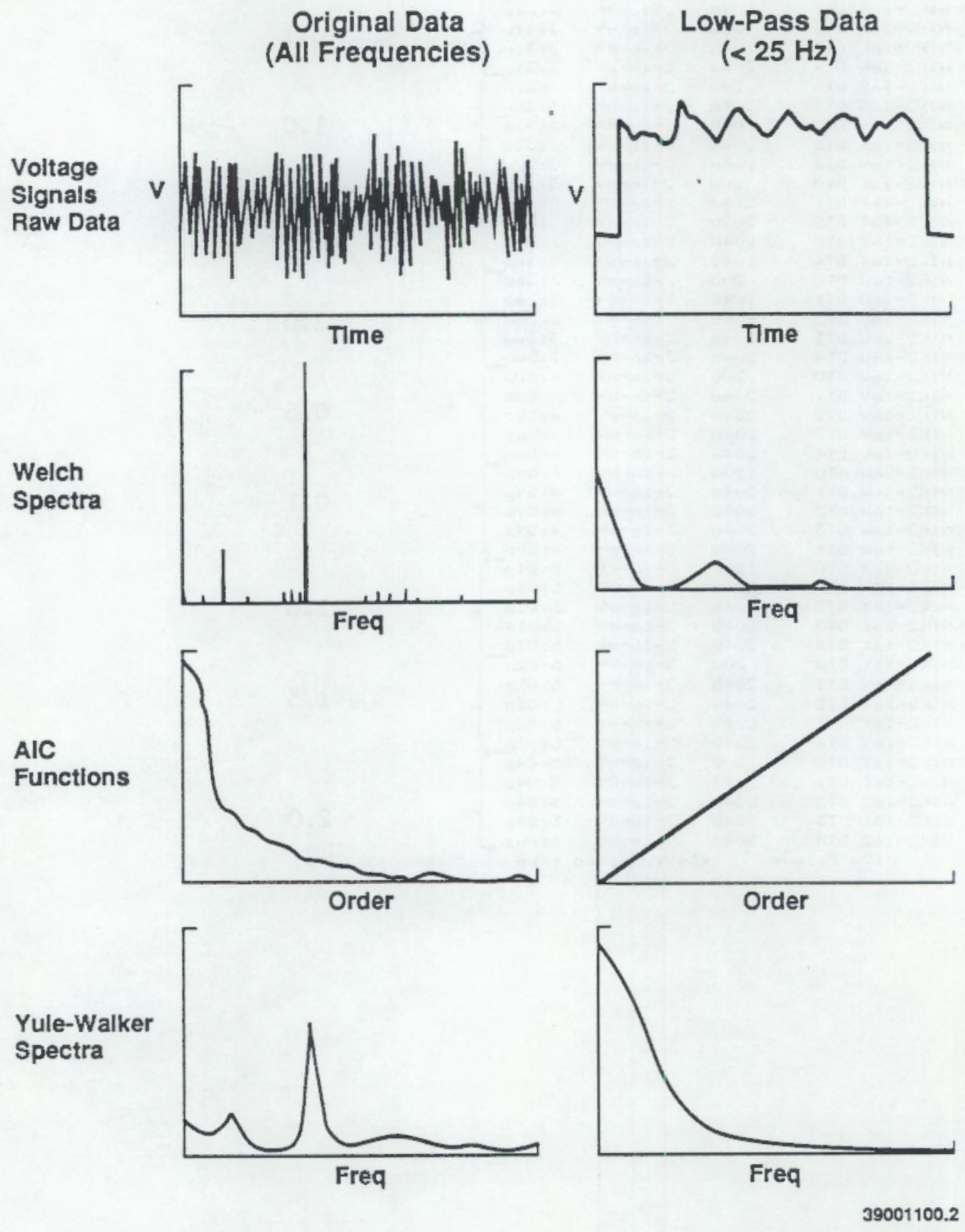

FIGURE 2.2. Examples of DSA Plots 
The above correlations for the PNL bench-scale laboratory cell data are shown in Figures 2.3 through 2.6. (Also shown are correlations for the Prototype Inert Anode Test, which will be discussed in Section 2.2.)

In addition to the correlations involving current density, some quantification parameters appeared to be affected by alumina concentration, albeit over a very narrow range. For example, as shown in Figures 2.7 and $2.8, R(0)$ for both the original current signals and the low-passed current signals changes significantly as alumina concentration changes from $20 \%$ to $40 \%$ of saturation. There is less sensitivity at values above and below this transition point. Other parameters, including $P(1) / R(0)$, also showed a similar behavior.

It is important to note at this point that the dependencies on current density and alumina concentration noted above, while interesting in their own right and possibly indicative of the mechanisms of the various anode properties/reactions, are not sufficiently refined yet to serve as a basis for a viable sensor. The current density dependency is weak at current densities at or below $1.0 \mathrm{~A} / \mathrm{cm}^{2}$, suggesting that either improvement in analytical sensitivity or a change in experimental procedure is warranted. Because alumina concentration is one of the main cell conditions for which a sensor is required, the dependency will ultimately have to be related to alumina concentration. At this point, the alumina concentration dependency is unacceptable, showing significant sensitivity only between $20 \%$ and $40 \%$ of saturation. Clearly, further work is needed to advance these or other preliminary parameter correlations to a stage where they are useful for a DSA-based sensor.

Other observations that were made by Dr. Nikias and described in his report of September 30,1989, were less promising for a sensor or less developed (due to the need for more data) at this time. These include the following:

For Original Data (all frequencies from 0 to $2.5 \mathrm{kHz}$ ):

- The mean value of both current and voltage signals appears to be insensitive to current density (CD) and alumina concentration changes. 


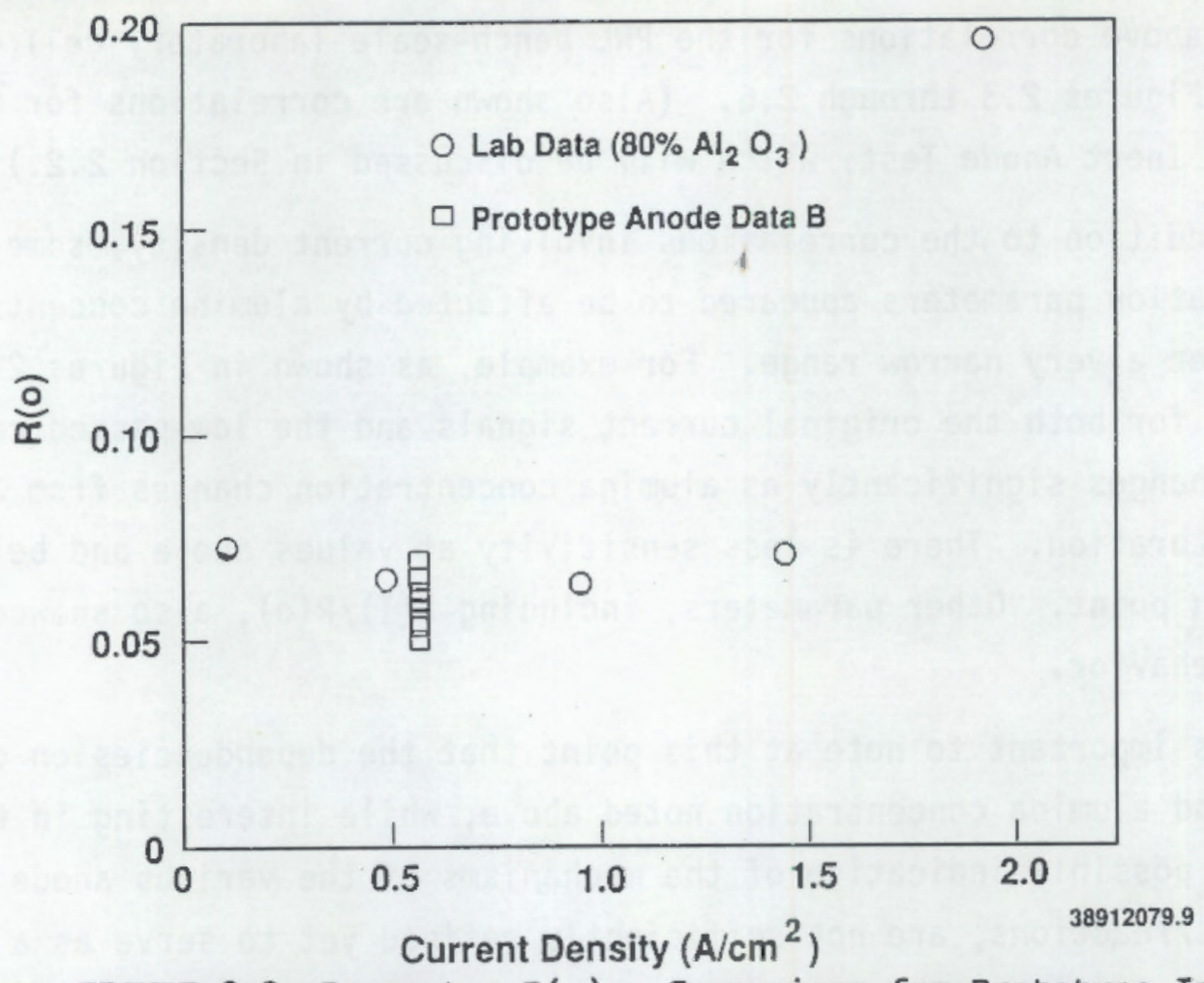

FIGURE 2.3. Parameter $R(0)$ : Comparison for Prototype Inert Anode Data B Low-Passed Voltage Signals

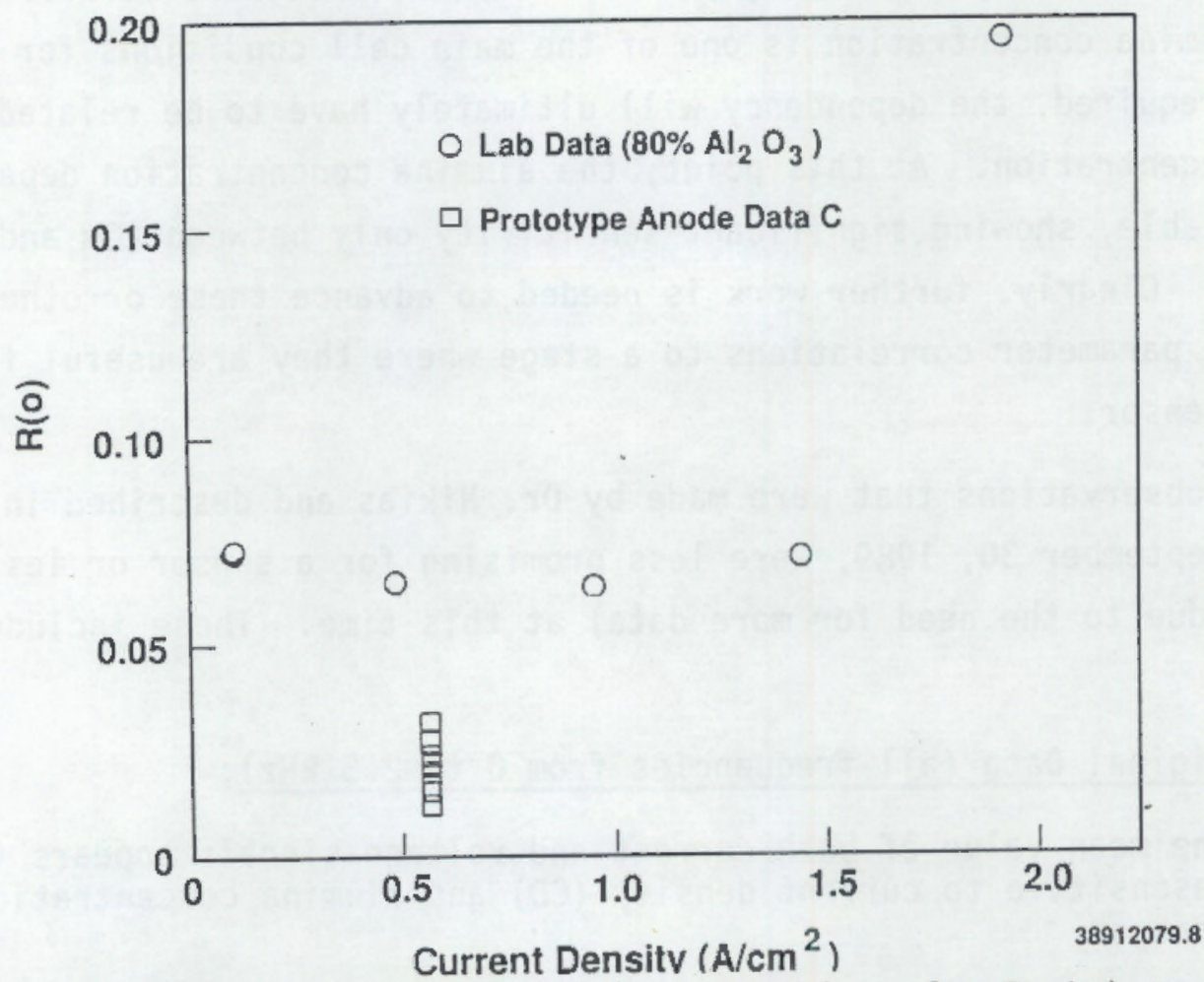

FIGURE 2.4. Parameter $\mathrm{R}(0)$ : Comparison for Prototype Inert Anode Data C Low-Passed Voltaqe Siqnals

2.10 


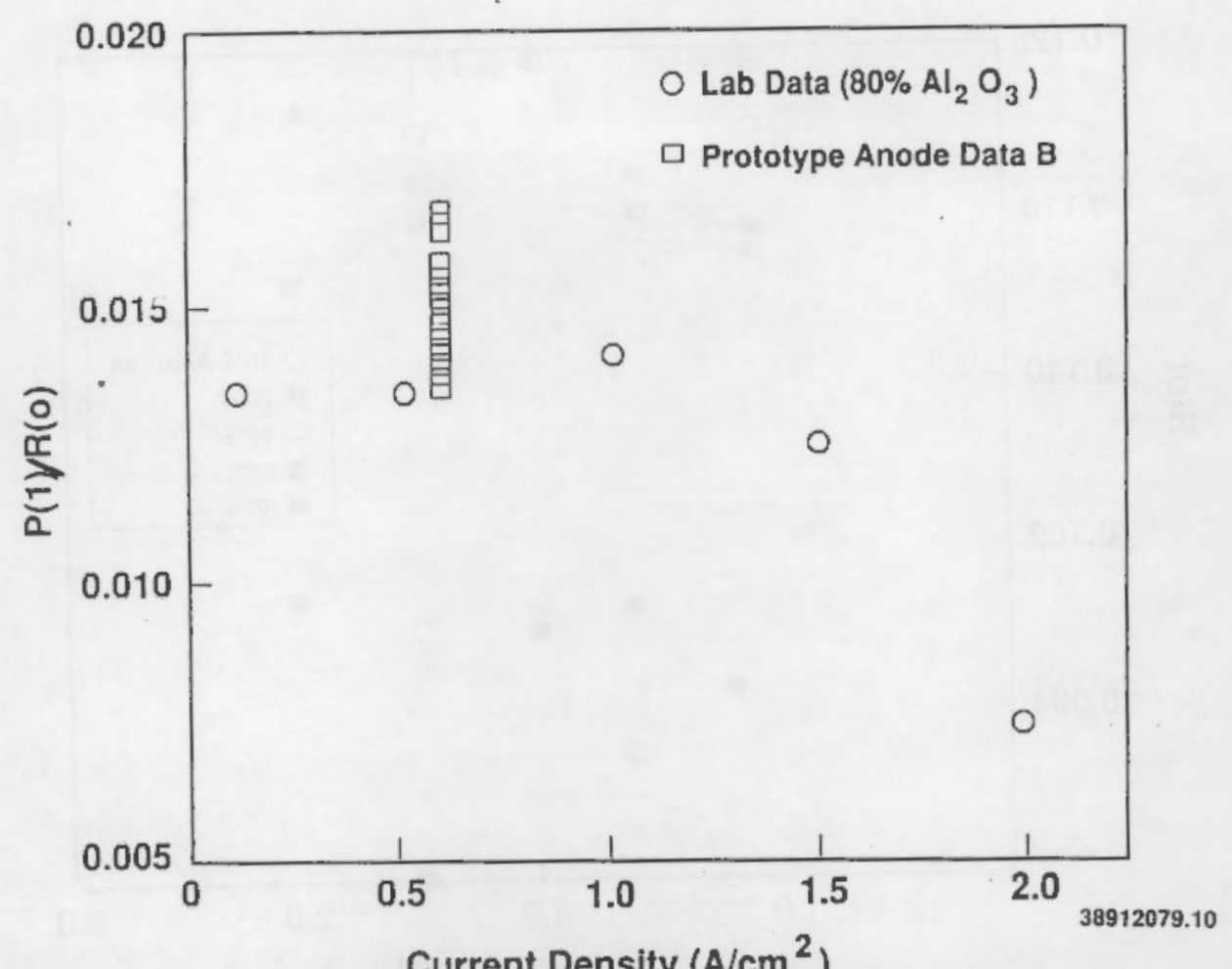

FIGURE 2.5. Parameter $P(1) / R(0)$ : Comparison for Prototype Inert Anode Data B Low-Passed Voltage Signals

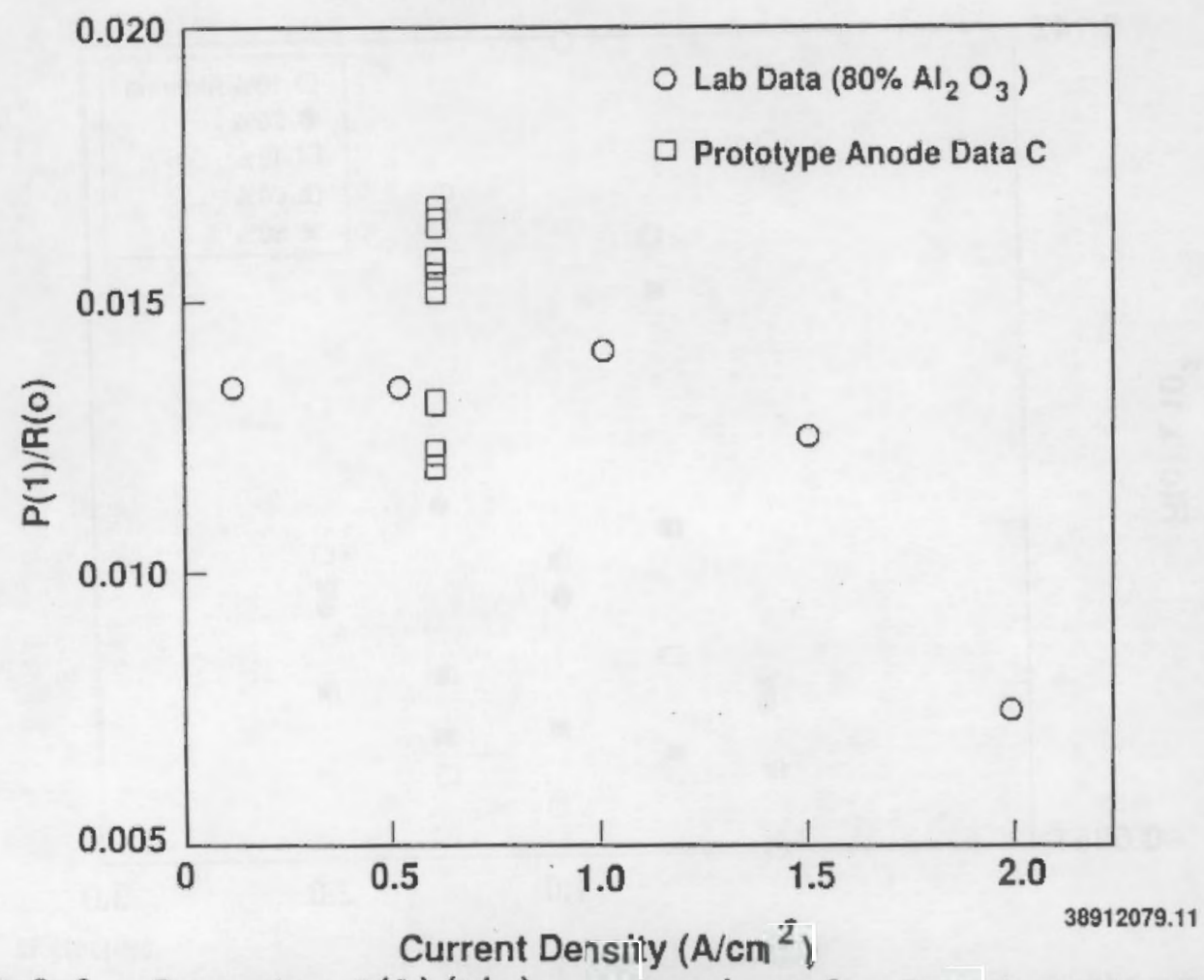

FIGURE 2.6. Parameter $\mathrm{P}(1) / \mathrm{R}(0)$ : Comparison for Prototype Inert Anode Data C Low-Passed Voltage Signals 

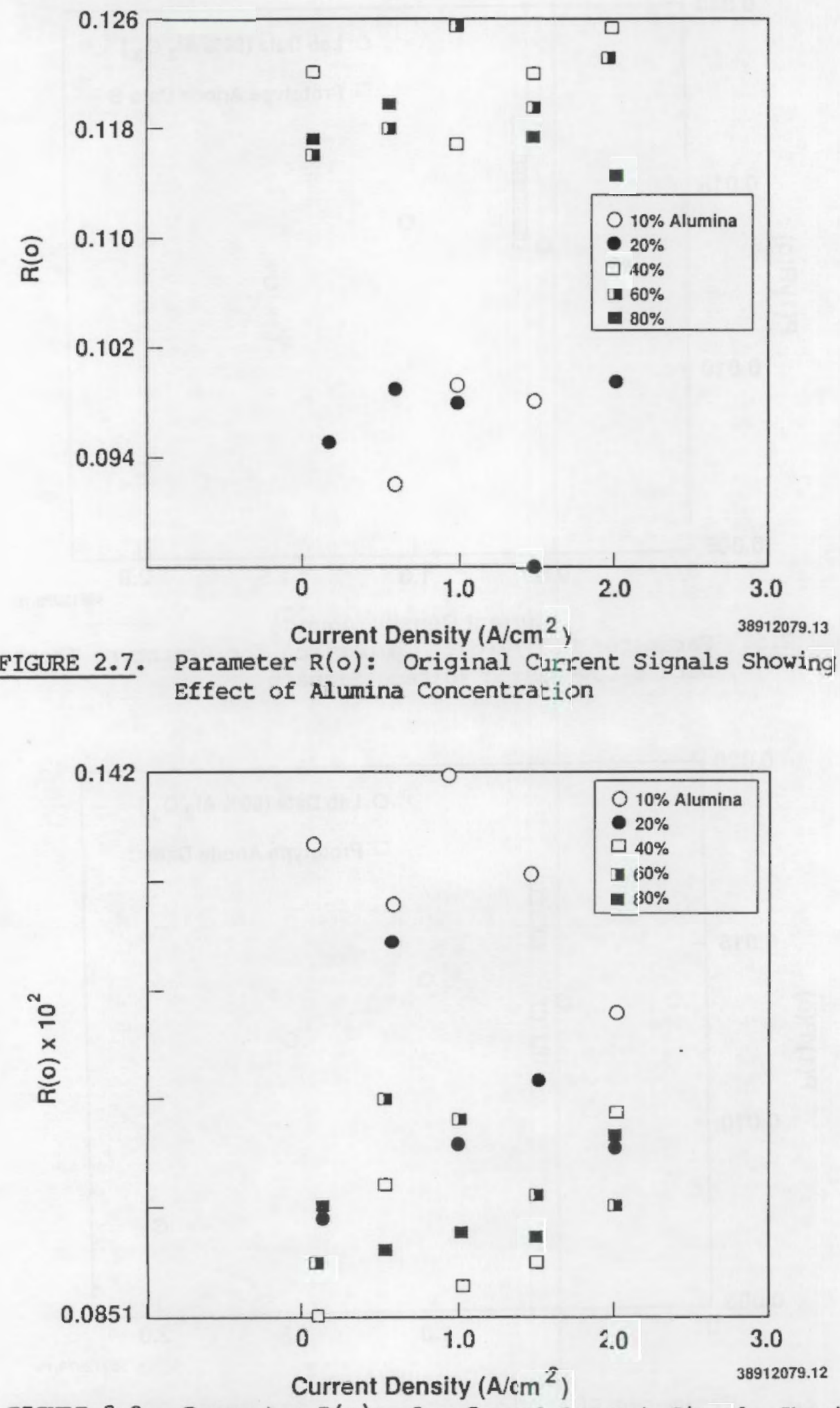

FIGURE 2.8. Parameter $R(0)$ : Low-Passed Current Signals Showing Effect of Alumina Concentration 
- The $P(1)$ parameter of the current signals is insensitive to $C D$ and alumina concentration. However, the $P(1)$ of voltage signals decreases in value when alumina increases from $20 \%$ to $40 \%$.

- The $R(0)$ of the current signals is insensitive to $C D$, and $R(0)$ for the voltage signals is insensitive to $C D$ and alumina.

- $P(1) / R(0)$ and $P(15) / R(0)$ for current signals are insensitive to $C D$, but for voltage signals they are sensitive to $C D$. As mentioned above, these parameters appear to show some sensitivity to alumina concentration, particularly between $20 \%$ and $40 \%$ of saturation.

For Low-Passed Data (frequencies from 0 to $25 \mathrm{~Hz}$ ):

- The mean value of both current and voltage signals is insensitive to electrochemical parameters $C D$ and alumina concentration. $P(1)$ also appears to be insensitive.

- $R(0)$ of the current signals is insensitive to current density.

- The first-, second- and third-order moments [M(1), M(2), M(3)] of the estimated power spectral density of current signals are sensitive to $C D$ for constant alumina concentration. It appears that the relationship between moments and $C D$ is highly nonlinear (of "sinusoidal wave" nature) for alumina between $10 \%$ and $40 \%$ of saturation. When alumina is at $60 \%, M(1)$ and $M(2)$ increase when $C D$ increases; $M(3)$ sightly decreases and then also increases. Finally, when alumina is at $80 \%$ of saturation, the relationship between $M(1)$ and $C D$ is strongly linear. On the other hand, as CD increases, $M(2)$ and $M(3)$ decrease significantly. So, current density does change the range of low frequencies where there is significant power concentration.

- The $M(1), M(2), M(3)$ moments of the estimated power spectral density of voltage signals do vary in value with current density for constant alumina concentration. As CD increases from 0.1 to $2.0 \mathrm{~A} / \mathrm{cm}^{2}$, the moments initially decrease slightly and then increase significantly. The minimum occurs either at 0.5 or 1.0 $\mathrm{A} / \mathrm{cm}^{2}$. The most dramatic increase occurs when $\mathrm{CD}$ changes from 1.5 to $2.0 \mathrm{~A} / \mathrm{cm}^{2}$ and alumina is at $10 \%, 20 \%$, and $80 \%$ of saturation.

- The relationship between moments and alumina concentration for constant CD appears to be of a "sinusoidal wave" nature in both current and voltage signals.

- The strongest magnitude-squared coherence (MSC) between low-passed current and voltage signals occurs when alumina concentration is $80 \%$ of saturation and appears to be weakening as CD increases. For this case, $0.3<\mathrm{MSC}<0.8$. In a11 other cases MSC $<0.35$ except when $C D$ is $1.5 \mathrm{~A} / \mathrm{cm}^{2}$ and alumina is $20 \%$ (MSC $\left.=0.6\right)$. 
- From the nonlinear modeling of the data we observed a strong linear relationship between current and voltage signals. This is apparent from the values of $A_{1}, B_{1}$ parameters, which are larger than the values of $C_{11}, C_{12}, C_{22}$. The parameters $C_{11}, C_{12}, C_{22}$ do not seem to change in value with alumina concentration or $C D$. However, $\mathrm{A}_{1}$ and $B_{1}$ remain relatively constant when $C D$ changes from 0.1 to 1.5 $\mathrm{A} / \mathrm{cm} 2$, and then increase significantly when $C D$ takes the value 2.0 $\mathrm{A} / \mathrm{cm}^{2}$.

\subsubsection{Conclusions}

In the current and voltage signal data from PNL bench-scale laboratory tests, correlations appear to occur between certain DSA-derived signal quantification parameters and certain cell operating conditions, especially current density. Although these correlations are encouraging, their significance for a DSA-based sensor, particularly for alumina concentration, is not yet clear. Further development work is required to determine whether these parameters can be made more sensitive to alumina or whether other parameters derived from other types of experiments will show stronger or more useful correlations.

\subsection{PROTOTYPE INERT ANODE TEST}

The Prototype Inert Anode Test was performed at the Reynolds Metals Company Manufacturing Technology Laboratory facilities, Sheffield, Alabama, in March 1989. The objective of the test was to determine if an anode produced by a commercial vendor could survive under conditions approximating those in a commercial electrolysis cell. Two types of current and voltage data were collected during the study: a) analog current and voltage signals that were used to evaluate the stability of the operation of the prototype inert anode while the test was being performed, and b) digital current and voltage signals that were analyzed at a later date to determine whether DSA methodology could be used to monitor and control aluminum smelting operations involving inert anodes.

\subsubsection{Experimental Setup}

The Prototype Inert Anode Test is described in detail (Strachan et al. 1990; Peterson et al. 1990). Briefly, a large 15-cm-diameter by 20-cm-high PNL cermet inert anode was tested for $113.5 \mathrm{~h}$ at a nominal current density of 
$0.6 \mathrm{~A} / \mathrm{cm}^{2}$. During the test, the anode operated smoothly, but post-test analyses revealed significant amounts of corrosion of the cermet material.

Several types of sensor and instrument combinations were used during the Prototype Inert Anode Test to monitor current and voltage signals for on-line and post-test evaluations conducted by PNL. The data for PNL work included digital current and voltage, analog data obtained with strip chart recorders, reference anode data, and data for CD calculations.

\subsubsection{Digital Signal Data}

Digital signal data for DSA obtained during the test consisted of the following:

A. cell current

B. cell voltage from top of working anode stem to cathode

C. cell voltage from inner surface of working anode to cathode

D. voltage from reference anode to cathode.

The measurements were made using the instruments and sensors assembly shown in Figure 2.9. An IBM AT was used with the Rapid Systems, Inc., R360 Real Time Spectrum Analyzer software for data acquisition, control, and storage. Signals were input to the IBM AT using the spectrum analyzer, which consists of a R300 digital signal processing interface board and the $4 \times 4$ digital oscilloscope peripheral. Inputs to the $4 \times 4$ included the cell current (A) collected across a transducer in the working anode stem, the cell voltage from the top of the working anode step to the cathode (B), the cell voltage from the inner surface of the working anode to the cathode (C), and the voltage from the reference anode to the cathode (D).

The reference anode was a cermet electrode with the same composition as the working anode but of smaller dimensions; its length was $2.5 \mathrm{in}$. with a diameter of $0.34 \mathrm{in.}$ This electrode was used as a reference against which the potential of another electrode could be measured. Key to the success of this procedure was the stability of the reference anode. To keep it from corroding, a small anodic current was passed through it throughout the test. 


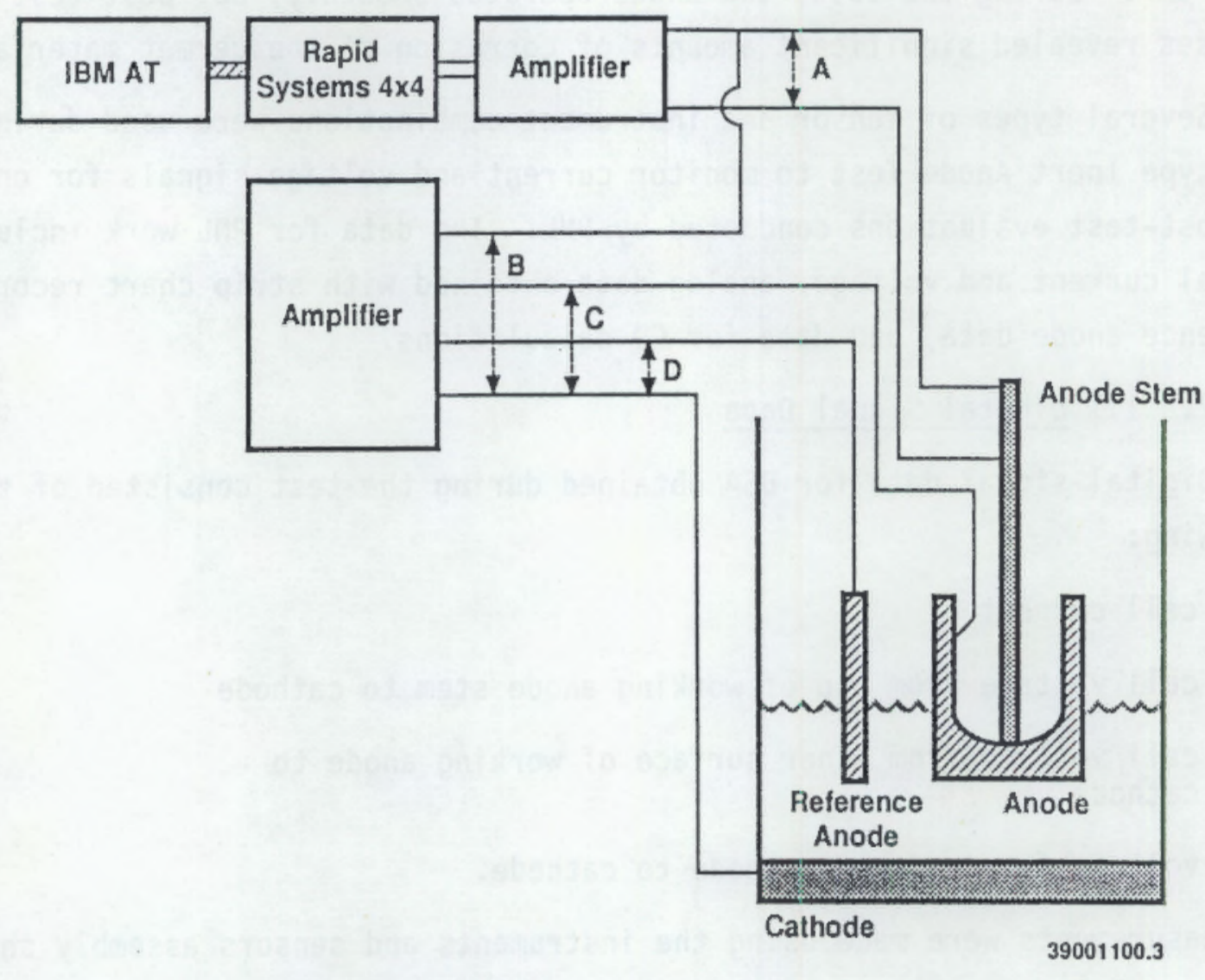

FIGURE 2.9. Sensor and Instrument Assembly for Digital Signal Monitoring in the Prototype Inert Anode Test

The data were collected in the form of sets of digital signals of items A through $D$ recorded at selected times during the test. Each set of data consisted of 2048 sequential signals collected over a period of $0.4 \mathrm{~s}$ ( $5 \mathrm{kHz}$ sampling frequency). During this short period of data collection, the cell operating conditions, including temperature and bath composition, were assumed to be constant.

The digital signal data were stored as files on $1.2 \mathrm{MB}$ magnetic disks. The cell operating conditions at the approximate times each set of data were collected are given for these files in Table 2.2.

The digital signal data were forwarded to Dr. C. L. Nikias, Professor, and Director of the Center for Digital Signal Processing Research, Northeastern University, Boston, Massachusetts, on May 26, 1989, for analys is under a subcontract with PNL. 
TABLE 2.2. Description of Conditions at Data Collection Times For Prototype Inert Anode Test

\begin{tabular}{|c|c|c|c|c|c|c|c|}
\hline File & Date & Time & Temp. & Volts & Amps & B.R. & $\mathrm{OAl}_{2} \mathrm{O}_{3}$ \\
\hline $\begin{array}{l}\text { NIKRSAT } \\
\sigma-9\end{array}$ & $3 / 20 / 89$ & 22.35 & $973^{\circ} \mathrm{C}$ & 3.69 & 120.6 & $\begin{array}{c}1.45 \\
.\end{array}$ & 8.03 \\
\hline $\begin{array}{r}\text { NIKRSA } \\
20-22\end{array}$ & $3 / 21$ & 10.38 & 992 & 3.50 & 120.7 & 1.35 & 7 \\
\hline $\begin{array}{r}\text { NIKRSA } \\
23-25\end{array}$ & $3 / 21$ & 17.01 & 980 & 3.45 & 120.7 & 1.34 & 7.91 \\
\hline $\begin{array}{r}\text { NIKRSA } \\
27-29\end{array}$ & $3 / 21$ & 19.55 & 979 & 3.65 & 139.5 & 1.32 & 7.59 \\
\hline $\begin{array}{r}\text { NIKRSA } \\
30-32\end{array}$ & $3 / 22$ & 11.29 & 972 & 3.57 & 121.5 & 1.28 & 7.53 \\
\hline $\begin{array}{r}\text { NIKRSA } \\
3 \mathrm{~A}-3 \mathrm{~B}\end{array}$ & $3 / 22$ & 19.18 & 981 & 3.52 & 120.5 & 1.27 & 7.55 \\
\hline NIKRSA 37 & $3 / 22$ & 22.30 & 967 & 3.24 & 83.0 & 1.26 & 8.09 \\
\hline $\begin{array}{r}\text { NIKRSA } \\
40-42\end{array}$ & $3 / 23$ & 8.24 & 989 & 3.53 & 120.4 & 1.26 & 7.77 \\
\hline $\begin{array}{r}\text { NIKRSA } \\
43-45\end{array}$ & $3 / 23$ & 10.27 & 985 & 2.96 & 120.5 & 1.26 & 9.43 \\
\hline $\begin{array}{r}\text { NIKRSA } \\
46-48\end{array}$ & $3 / 23$ & 14.50 & 989 & 3.68 & 120.4 & 1.26 & 9.11 \\
\hline $\begin{array}{r}\text { NIKRSA } \\
49-4 B\end{array}$ & $3 / 23$ & 19.15 & --- & --- & -- & 1.32 & 8.46 \\
\hline $\begin{array}{r}\text { NIKRSA } \\
50-52\end{array}$ & $3 / 24$ & 10.15 & -- & 3.68 & 120.6 & 1.28 & 8.68 \\
\hline $\begin{array}{r}\text { NIKRSA } \\
56-58\end{array}$ & $3 / 24$ & 13.40 & 982 & 3.75 & 120.4 & --- & 7.93 \\
\hline $\begin{array}{r}\text { NIKRSA } \\
59-5 B\end{array}$ & $3 / 24$ & 18.50 & 987 & 3.25 & 119.5 & 1.29 & 8.75 \\
\hline $\begin{array}{r}\text { NIKRSA } \\
5 Y-5 W\end{array}$ & $3 / 24$ & 19.50 & 983 & 3.89 & --- & --- & 7.6 \\
\hline $\begin{array}{r}\text { NIKRSA } \\
5 E-5 G\end{array}$ & $3 / 24$ & 22.45 & 974 & 3.89 & 119.4 & --- & 7.83 \\
\hline $\begin{array}{r}\text { NIKRSA } \\
6 A-6 B\end{array}$ & $3 / 24$ & 23.45 & --- & 3.85 & 119.4 & 1.26 & 8.93 \\
\hline $\begin{array}{r}\text { NIKRSA } \\
61-62\end{array}$ & $3 / 24$ & 8.12 & 987 & 3.95 & 119.7 & -- & 8.01 \\
\hline $\begin{array}{r}\text { NIKRSA } \\
64-66\end{array}$ & $3 / 24$ & 9.16 & 952 & $-\cdots$ & -- & --- & 8.18 \\
\hline
\end{tabular}




\subsubsection{Other Digital Data}

In addition to data collected for analys is by Or. Nikias, other digital signal data were analyzed in various ways to determine, in particular, the variations of current and voltage over longer time durations than those appropriate for standard DSA. The same instrumentation described above was used to collect these additional digital signal data. It turns out that most of these additional data showed little, if any, variation with time, and therefore resembled the $D C$ current.

\subsubsection{Analog Data}

Strip chart recorders were used to monitor certain cell operating conditions. These conditions were the following:

R1. cell voltage

R2. voltage from working anode to reference anode

R3. current through the reference anode

R4. root mean (RMS) square voltage.

The recorders were hooked up to the prototype anode cell as shown in Figure 2.10.

\subsubsection{Results}

\subsubsection{Digital Signal Analysis}

The results of Dr. Nikias' analysis of the Prototype Anode DSA data are reported in the progress report submitted to PNL. on September $30,1989$. (a) Dr. Nikias performed additional analyses of these data and reported his conclusions to PNL in a letter dated November 7, 1989. The following is a summary of Dr. Nikias' findings; the more recent analyses are emphasized.

One of the principal issues regarding correlations for data from the PNL bench-scale laboratory cells is whether they can be applied with confidence to full-size commercial aluminum reduction cells. Consequently, the approach taken for the analysis of the Prototype Inert Anode data was to determine the

(a) Nikias, C. L. 1989. Advanced Signal Analysis Methods for Aluminum Smelting Data: Preliminary Progress Report for Period June 18, 1989 to September 30,1989, Northeastern University, Boston, Massachusetts. 


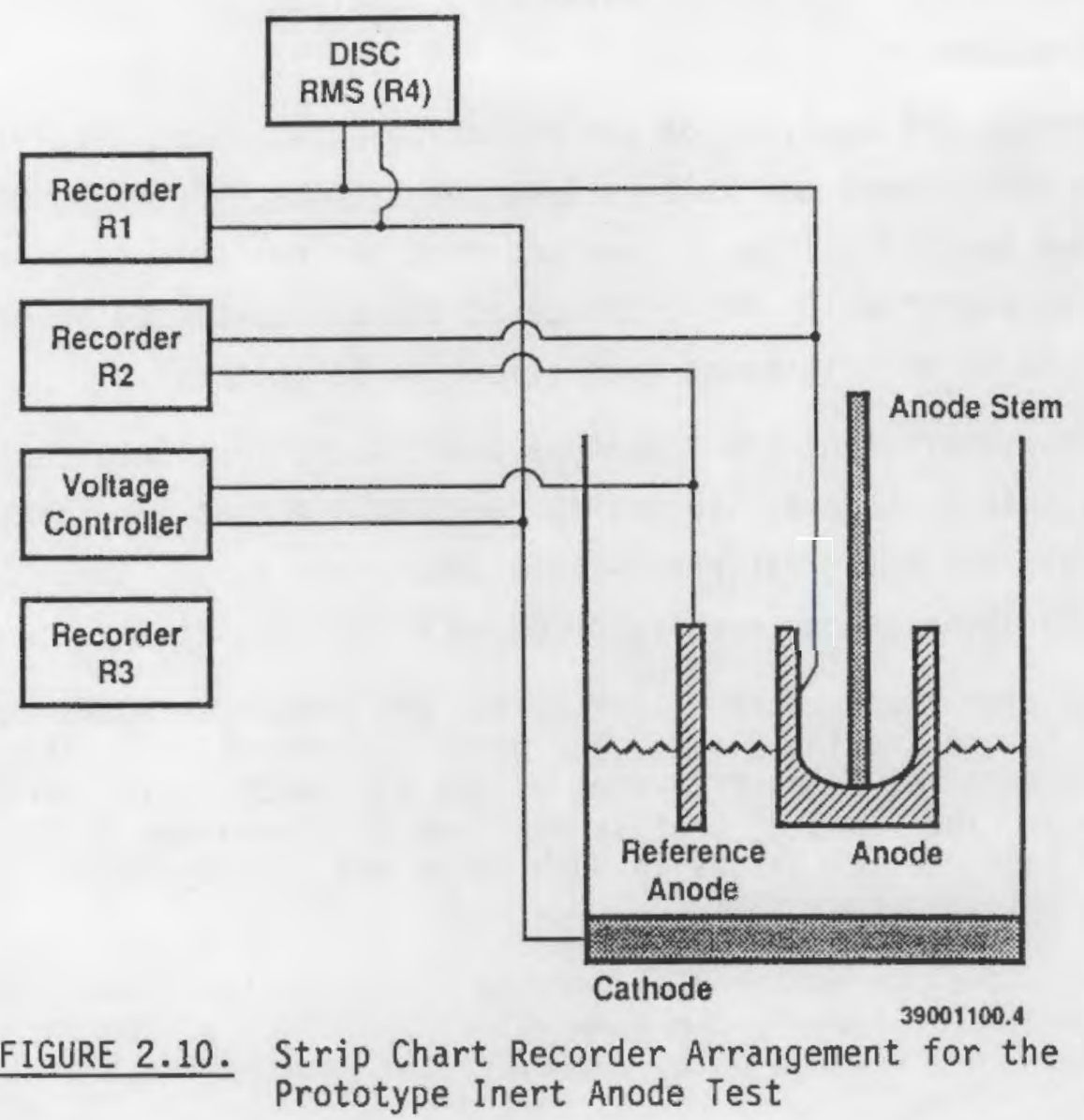

quantification parameters for these data and then compare them to quantification parameters and their correlations obtained using PNL benchscale laboratory data. Similarity in these quantification parameters is interpreted to suggest a correlation with general applicability to aluminum reduction cells using inert anodes with no significant effect due to scaleup.

The same DSA techniques that were used on the PNL bench-scale laboratory cell data were used to analyze current and voltage signals from the Prototype Inert Anode Test. These techniques, which are described in the Appendix, are the Welch (FFT-based), Yule-Walker (YW) autoregression (AR), and magnitudesquared coherence (MSC) methods, and nonlinear second-order volterra modeling. As indicated previously, and shown in Figures 2.3 through 2.6, the quantification parameters $\mathrm{R}(0)$ and $\mathrm{P}(1) / \mathrm{R}(0)$ obtained from low-passed $(<25 \mathrm{~Hz})$ voltage signals appear to show some correlation with working anode 
current density. The correlations were observed over a range of alumina concentrations.

Preliminary analyses of the Prototype Inert Anode data(a) indicated that signals for current and voltage from the Prototype Inert Anode Test usually contained several spikes or impulses that did not seem to correlate with cell operating conditions. The presence of the spikes caused severe changes in the values of the estimated quantification parameters.

Reexamination of the Prototype Inert Anode Test data that did not exhibit spikes, however, suggested correlations that were consistent with those observed using PNL bench-scale laboratory data. Specifically, the following observations were reported to PNL by Dr. Nikias.

- The signal parameter $P(1) / R(0)$ for the Prototype Anode voltages $B$ and $C$ (refer to Section 2.1.2.2 for notation definitions) takes approximately the same values as $P(1) / R(0)$ of the PNL bench-scale laboratory voltage data. The "spread" that is observed in the values of $P(1) / R(0)$ is perhaps due to changes in bath ratio and $\% \mathrm{Al}_{2} \mathrm{O}_{3}$ during the data collection processes.

- The signal parameter $\mathrm{R}(0)$ for the Prototype Inert Anode Test voltage B takes approximately the same values with $R(0)$ as the PNL bench-scale laboratory voltage data. However, the $\mathrm{R}(0)$ of the Prototype Inert Anode Test voltage $C$ takes values that are approximately $30 \%$ of those obtained using PNL bench-scale laboratory voltage data.

To illustrate the above consistencies between the Prototype Inert Anode Test data and the PNL bench-scale laboratory data, the two are plotted together in Figures 2.3 through 2.6. As indicated above, the quantification parameters for the Prototype Inert Anode Test voltages $B$ and $C[P(1) / R(0)]$ that were obtained at a nominal current density of $0.6 \mathrm{~A} / \mathrm{cm}^{2} \mathrm{fall}$ in a range that is consistent with a similar current density for the PNL bench-scale laboratory data. These results suggest that the observed correlations are general and not strongly dependent on scale-up considerations.

The Prototype Inert Anode Test signals B and C are both cell voltages and differ only in where the anode tap was made. For $B$, the anode tap was at the anode stem; for $C$, the tap was on the inner surface of the working anode.

(a) Nikias, C. L. 1989. Advanced Signal Analysis Methods for Aluminum Smelting Data: Preliminary Progress Report for Period June 18, 1989 to September 30,1989, Northeastern University, Boston, Massachusetts. 
It is reasonable that these voltage signals showed some correlation with the current density since electrode processes, which influence the extent of voltage noise, may vary over the range of current densities studied. It is not clear, however, why $C$ in the case of $R(0)$ showed poor correlation; it may have to do with the integrity of the inner anode connection. The fact that $A$ does not correlate is not surprising. Because the cell was under current control, the contribution of process-derived noise to this signal was less. Lack of correlation of $D$ may be explained by the less-than-adequate performance of the reference anode (described later in this report).

\subsubsection{Analog Data Analysis}

Analog data for the various voltages and currents measured with strip chart recorders (see Section 2.2.1.3) were generally stable except for periods when parameters were deliberately adjusted. For example, current versus voltage sweeps were occasionally performed during cell operation for diagnostic purposes. All of these data indicated no serious instabilities or deviations from what would be considered stable cell operation. It is not clear at this time why there was no indication in the analog data of the corrosion processes the inert anode clearly underwent. It is possible the anode's larger size (compared with that of laboratory cells) resulted in a different sensitivity to these processes, but adequate size-effects data are lacking for definitive conclusions in this regard.

\subsubsection{Conclusions}

Analyses of DSA data from the Prototype Inert Anode Test suggested that the DSA approach to monitoring selected cell operational parameters may be viable for large-scale cells if it can be shown to be viable for bench-scale cells. Correlations of current density with certain DSA quantification parameters have been observed, but the significance of these correlations is not yet clear. Any correlations with alumina concentration that could be a workable basis for an alumina sensor are not obvious from the current set of laboratory data.

Analog signals showed no indication of the corrosion observed in posttest analyses on the Prototype Inert Anode. This may be related to scale-up considerations. 



\subsection{DEVELOPMENT OF THE REFERENCE ANODE}

The concept of a "reference anode" (RA) was developed in FY 1988 as a way to monitor the stability of the working inert anode during electrolys is in an aluminum reduction cell. The RA has the same composition as the working inert anode (the reason it's called an "anode") but has only a small voltage applied to it to maintain the minimal current required to "passivate" it. Previous work at PNL had suggested that a protective reaction layer forms on inert anodes during anodic polarization in alumina-containing molten cryolite. When no current is applied, the anode material has been observed to corrode severely.

The key to success for this and any reference electrode is that its potential must be invariant in the electrolytic medium. If this condition is met, then the potential of any working anode can be measured against it. Instabilities in the working anode should then be reflected in the anode-toreference potential in the form of "spikes" or "noise."

The majority of the studies conducted in the FY 1989 Sensors Development Program through April 1989 were conducted in support of the laboratory and field development and evaluation of the RA. This work included the following:

- Attempts were made to locate potential manufacturers of the RA; none were found.

- In-house efforts to manufacture an RA with dimensions suitable for employment in larger cells were successful.

- Experiments were performed to determine how to condition the RA prior to its use as a reference. In particular, some experiments seemed to suggest a protective film could be put down on a RA in a aluminasaturated preconditioning bath and that this film would persist when the RA was placed in a bath with lower alumina concentrations.

- Experiments were performed using a RA that was bridged to the working anode via a $4 \mathrm{~K}$ resistor. This design was to allow a small amount of current through the RA so that a protective film would be maintained on it during electrolysis.

- Various methods, including the use of a root mean square voltmeter and a frequency counter, were evaluated in laboratory tests to monitor spikes in the working-anode-to-RA potential. The spikes are believed to arise from breakdown events in the working anode's protective reaction layer. 
- Experiments were conducted using the RA to monitor cell resistance as a function of current density and alumina concentration.

- RAs were constructed and employed in the Prototype Inert Anode Test conducted at the Reynolds Metals Company facilities, Sheffield, Alabama.

\subsection{PROTOTYPE INERT ANODE TEST}

Four RAs were used in sequence during the Prototype Inert Anode Test, which lasted for more than $100 \mathrm{~h}$. Two of the RAs were recovered. Two fell off their connector rods (as a result of the catastrophic corrosion of the connector rod) and into the reduction cell. Post-test examination of the recovered RAs showed that both had corroded severely during use. Figure 3.1 shows the extent of corrosion in one case.

The corrosion of the RA occurred despite attempts to protect it by impression of a small anodic current. It has been proposed that such a current should foster the formation of a protective film or reaction layer and thus minimize corrosion.

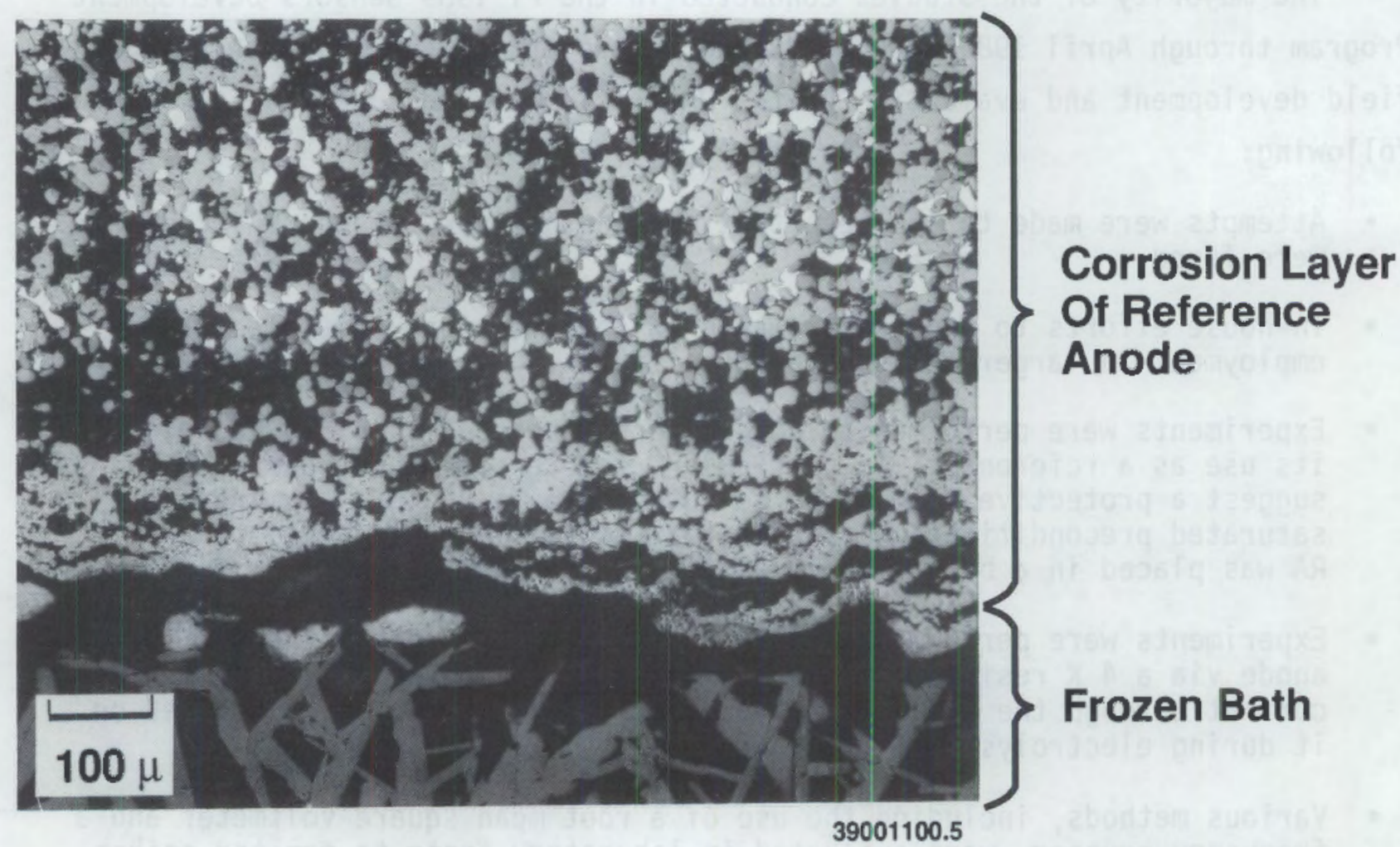

FIGURE 3.1. Corrosion of Reference Anode 
Because of constraints involving the larger cell used, the mode of operation chosen for the RA during the Prototype Inert Anode Test was constant voltage control. Previous tests had involved cyclically shunting the RA to the working anode to maintain the small anodic current. Under voltage control, the current required to maintain a protective layer on the RA was assumed to be determined by the RAs area of exposure to the molten bath and the alumina content of the bath as well as the control voltage. The control voltage was established by suming the theoretical open circuit cell voltage, the IR drop to the location of the RA (determined by the bath resistance and the operating current), and the cathode overvoltage at the operating current. The current required by the RA was recorded and assumed to be determined largely by the resistance of the protective layer and hence the alumina concentration. This assumes that the protective layer is dynamic in nature and has a resistance that is related to the alumina content of the bath, inversely proportional to the area of the RA exposed to the molten bath, and functionally related to the control voltage.

It was observed that the RA current was only slightly affected by the magnitude of the process current, although the control voltage used was considered to be less than its minimum value. The IR drop in the electrolyte was subsequently found to be indeterminate as a result of the dissolution and loss of integrity of the alumina cell liner. The RA current was generally noisy with a stable long-term trace, suggesting stable alumina content. An attempt to verify the response of the RA to variable alumina content was made during the termination of the experiment by stopping the addition of alumina. The results were inconclusive, however, since the alumina liner continued to dissolve and maintain an almost constant alumina content in the bath. The cell furnace failed, thereby terminating the test, before the alumina content changed significantly.

Other problems encountered during the test included a persistent variation of the surface area of the RA exposed to the molten bath, the condensation of electrically conducting bath vapors on all exposed surfaces, and the formation of a "bridge" of frozen bath above the surface of the molten bath which caused electrical shunting during the test. 
These Prototype Inert Anode Test results suggest that, despite the amount of effort expended in FY 1989 on the development of the RA, serious issues regarding the operation of the electrode and of its durability remain. The most important of these are summarized below.

- The viability of the RA in the Prototype Inert Anode Test was inconclusive at best. No significant indication was given by the RA that the working anode was experiencing severe corrosion. Its viability as an alumina sensor could not be determined because the cell was operated at essentially saturated alumina content throughout the test.

- The effects of the working anode's size on the magnitude and quantity of the proposed protective layer's-breakdown signals have not been fully determined.

- Since the RA must be operated with a small current flowing through it, a reliable circuit has to be designed to give this current and also to keep the RA potential constant. It is not clear whether this approach is even possible in an operating cell. Attempts to do this in the Prototype Inert Anode Test gave questionable results.

- The RA design has some serious mechanical problems incurred by - among other factors - the difficulty in joining the connector rod to a long, narrow cermet electrode.

- Laboratory results which showed that a protective film could be formed on the anode in an alumina-saturated bath and that the anode could be successfully removed with the film intact, are inconsistent with our failure to date to detect and identify the film in post-test optical analyses.

\subsection{RECOMMENDATION CONCERNING THE REFERENCE ANODE}

Because of the considerations discussed in Section 3.1, PNL recommended that further development of the reference anode be suspended and that the $\mathrm{Al} / \mathrm{Al}_{2} \mathrm{O}_{3}$ reference electrode, which has been used successfully in many shortterm tests, be employed as a substitute reference electrode in the Pilot Cell Test. This electrode is stable and should give a clear indication of any instability on the part of the working anode. Its principal limitation is that it is somewhat fragile and will have to be replaced periodically during the Pilot Cell Test.

Periodic replacement of the reference electrode presents merely an inconvenience for the Pilot Cell Test. However, it does present a severe limitation to employing it as a long-term monitor for the operation of the working anode. Consequently, if such a long-term monitor is required, 
laboratory work should continue in FY 1990 to develop one. As previously discussed, one approach would be to focus future research on developing a more effective alumina sensor using, for example, bath resistance - DSA correlations. Since alumina concentration and anode stability are related, a good method for measuring one should be a good method for monitoring the other.

\subsection{ELECTROCHEMICAL IMPEDANCE MEASUREMENTS}

During the evaluation of the RA in FY 1989, numerous studies were performed using PNL bench-scale laboratory cells to measure the impedance of the working inert anode with respect to the RA at various current densities and alumina concentrations. The purpose of this work was to see if an alumina-impedance relationship could be established that might serve as a basis for an alumina sensor.

The instrumentation for these studies varied from test to test, but in general involved the use of a transfer function analyzer and a potentiostat which, in combination, were used to determine the impedance of a working inert anode. Impedances were measured at a sufficiently high frequency to interrogate the purely resistive reaction layer (which has been shown in previous PNL work to form on inert anodes during aluminum electrolysis). The cell design was similar to that described in Section 2.1.2, except that a reference electrode (as described in Section 3.1) was employed.

As shown in Figure 3.2, definite trends in working anode impedances were observed as a function of current density and alumina concentration. All of the data seem to suggest that the electrode impedance is a minimum at a current density around $0.5 \mathrm{~A} / \mathrm{cm}^{2}$. Unfortunately, despite this persistent trend, there also occurred a wide variability in the absolute values of the impedances. This is demonstrated in Figure 3.3, where data are plotted for alumina at $80 \%$ of saturation at two different times during an experiment. Clearly, the large hysteresis effect limits the applicability of this approach as a sensor for alumina concentration. 


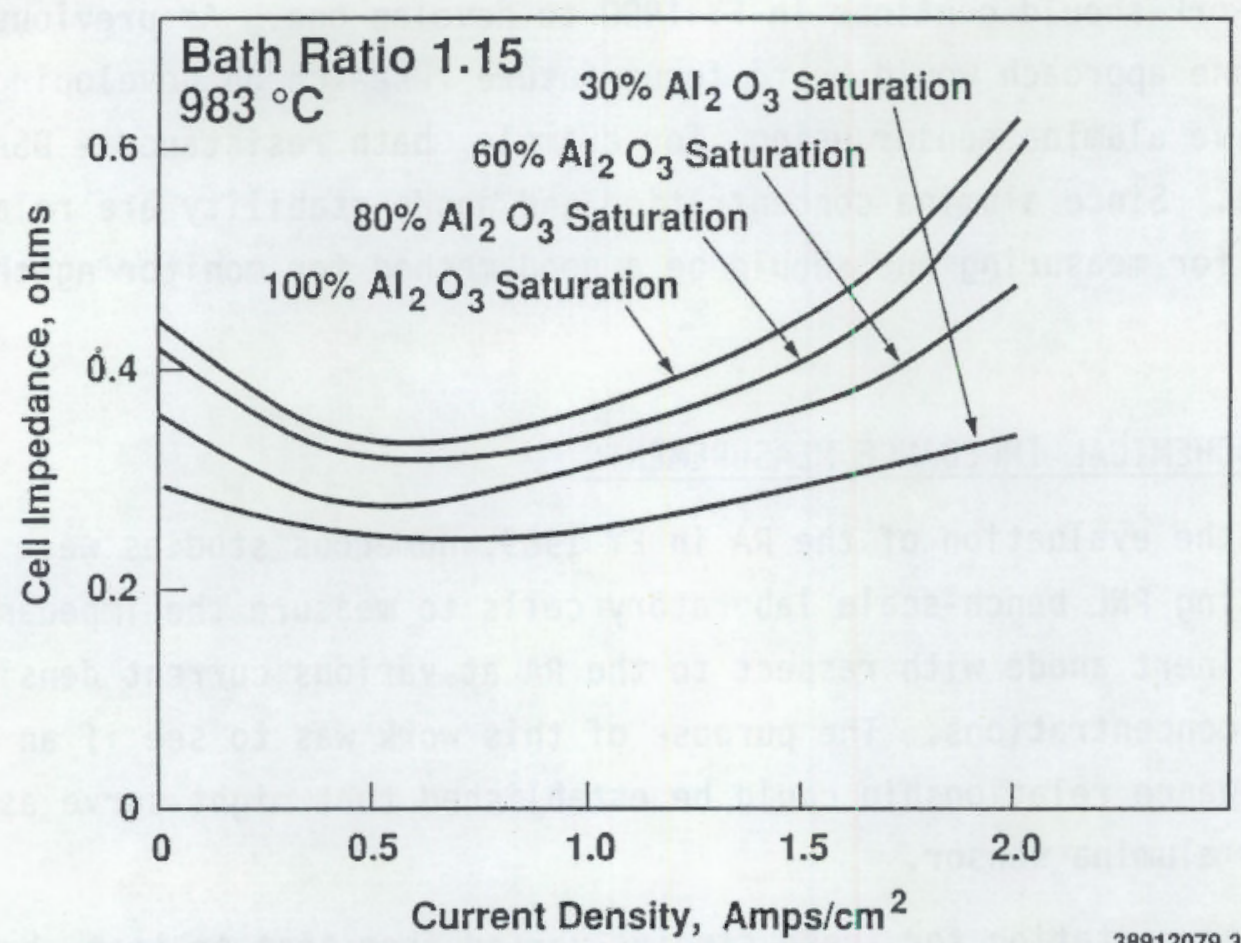

FIGURE 3.2. Resistance Versus Current Density with Percent Alumina Saturation Dependence

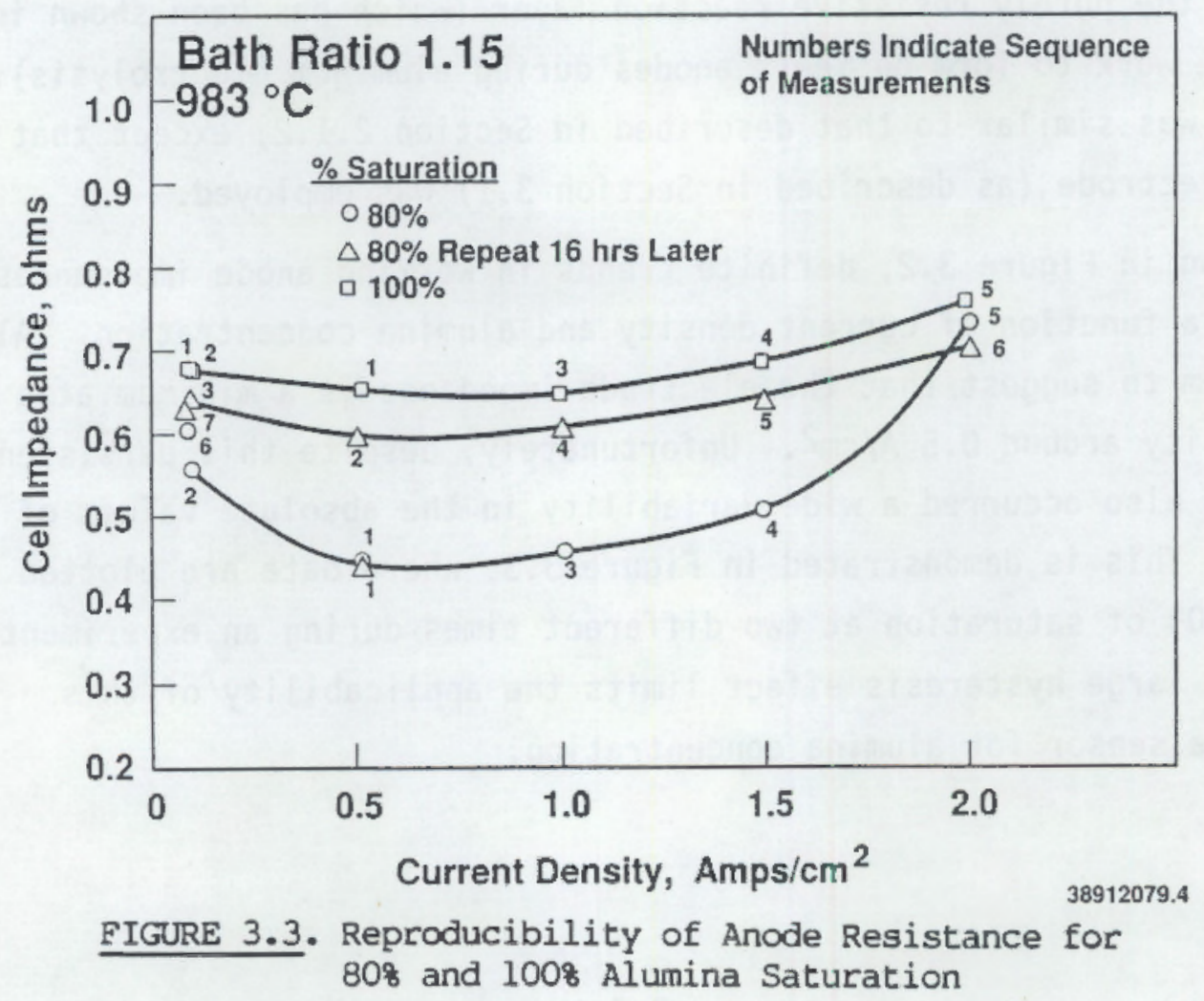




\subsection{FIELD TEST OF THE REFERENCE ANODE}

The Pilot Cell Test will evaluate a six-anode array of the full-scale inert anodes (same size as used in the Prototype Inert Anode Test) in a 30day test using a Reynolds Metals Company pilot-scale aluminum reduction cell. The objective of this task of the Sensors Development Program is to use DSAtype methods to evaluate the cell operating parameters, the operation of the inert anodes, and the performance of the reference anode, which was also to be incorporated into the anode assembly. The task involves procurement of instrumentation for collecting DSA-type data from the cell, setup and preliminary evaluation of the instrumentation in PNL facilities, participation in the actual field trial to obtain data, and subsequent data analyses.

\subsection{STATUS OF THE FIELD TEST}

Because of problems associated with procurement of the cermet inert anode raw materials and fabrication of the required number of anodes, the Pilot Cell Test was postponed to FY 1990. Consequently, the principal part of this task, the participation in the actual field trial, has been postponed to FY 1990.

During FY 1989, the instrumentation required for DSA data collection was procured and evaluated in preliminary tests using PNL bench-scale laboratory cells. A procedure was developed for DSA data collection using this equipment which will be transferred directly to the Pilot Cell Test. In addition, the method for anode potential measurement was changed. For reasons discussed in Section 3.0, a reference electrode based on the $\mathrm{Al} / \mathrm{Al}_{2} \mathrm{O}_{3}$ half-cell will be used instead of the cermet composition reference anode for monitoring the potential of the Pilot Cell anode array.

\subsection{PLAN FOR FIELD TEST}

The instrumental setup that will be used to obtain DSA data from the Pilot Cell Test is shown in Figure 4.1. It consists of an IBM AT using HEM Corporation Snapshot/Snap-Calc/Snap-Filter software for acquisition and analysis of current and voltage signals using $A / D$ data acquisition hardware 


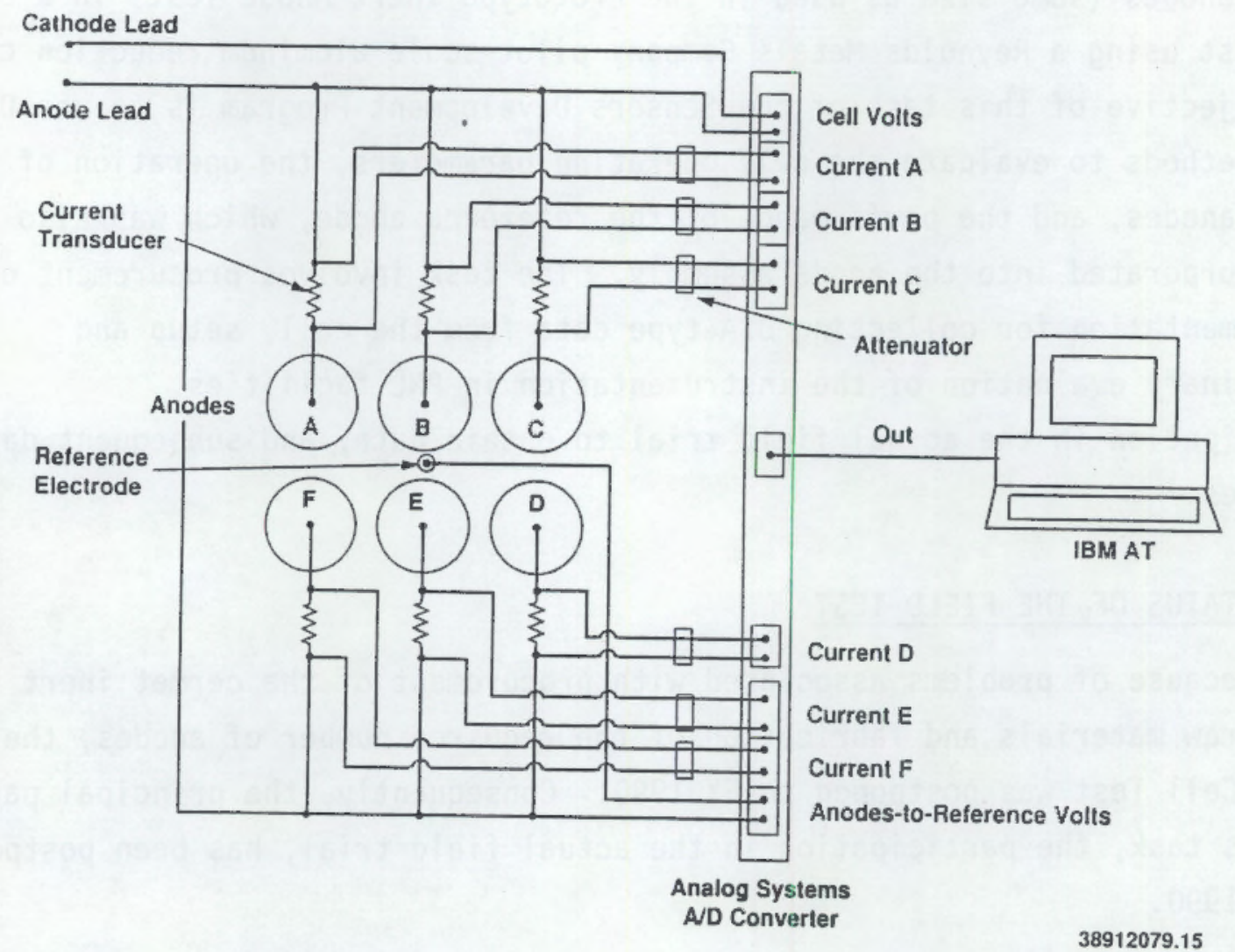

FIGURE 4.1. Pilot Cell Test Sensor Configuration

manufactured by Analog Devices, Inc., Norwood, Massachusetts. This instrument contains at least eight signal conditioning modules and a highspeed simultaneous data acquisition board. Eight channels will be monitored simultaneously using this setup. These data channels are the cell voltage, the anode array-to-reference electrode voltage, and the currents though each of the six anodes composing the six-anode array. The anode currents will be measured across current transducers that will be engineered into each of the anode "legs" by Reynolds Metals Company personnel.

The reference electrode will be the $\mathrm{Al}_{1} / \mathrm{Al}_{2} \mathrm{O}_{3}$ type, based on the design by Burgman, Leistra, and Sides (1986). The electrode has been shown to be stable and should give a clear indication of any instability on the part of the working anode array. Potentials of individual anodes cannot be measured 4.2 
because of the cell design. The principal limitation of the reference electrode is that it is somewhat fragile and will have to be replaced periodically during the Pilot Cell Test. Consequently, numerous reference electrodes will be assembled in preparation for the test.

Digital current and voltage data will be collected periodically throughout the test and during times when cell operating conditions are altered, in particular when current/voltage scans are performed and when alumina concentration is adjusted. Data will be collected in "bursts" at a sampling frequency of $20 \mathrm{kHz}$ over a period of $0.5 \mathrm{~s}$, and stored as files (each containing 10,000 samples) on $1.2 \mathrm{MB}$ floppy disks. The files will be submitted to Dr. Nikias at a later date for analysis. 
. - 


\subsection{CONCLUSIONS ANO FUTURE DIRECTIONS}

In FY 1989, results obtained at PNL and at the Prototype Inert Anode Test conducted at the Reynolds Metals Company facilities showed that there may be correlations between certain DSA quantification parameters and the current density of the working inert anode. Although some laboratory cell data show a dependence on alumina concentration, more work is needed to determine whether a correlation with this important cell operating parameter can be obtained which would form a viable basis for a DSA-based alumina sensor.

The lack of good sensitivity of the DSA-derived parameters to alumina concentration suggests that, if any correlation with alumina concentration exists, it is very weak and possibly obscured by fluctuations in other cell conditions. Research in FY 1990 will investigate the effects of these other conditions so as to isolate or magnify the dependency on alumina concentration. For example, if the DSA quantification parameters are found to be very sensitive to changes in bath resistance, experiments where the anode-to-cathode distance is varied while collecting OSA data may provide a correlation which could, ultimately, incorporate alumina concentration.

Other planned work for FY 1990 includes collection and analys is of DSA data from the Pilot Cell Test to be conducted at the Reynolds Metals Company facilities and evaluation of the applicability of other DSA techniques to sensor methodology. These other techniques include various nonlinear methods and chaos theory. Dr. Nikias will continue to assist PNL with DSA analyses under subcontract.

Because of problems encountered with the cermet composition reference anode, its further development will be postponed in FY 1990 . The focus of efforts in FY 1990 wil1 be to investigate and determine the viability of DSAbased methods of cell monitoring and control. $\mathrm{An} \mathrm{Al}_{1} / \mathrm{Al}_{2} \mathrm{O}_{3}$ reference electrode will be used in future tests including the Pilot Cell Test. 


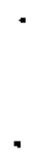

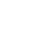




\subsection{REFERENCES}

Burgman, J. W., J. A. Leistra, and P. J. Sides. 1986. "Aluminum/Cryolite Reference Electrode for Use in Cryolite-Based Melts." J. Electrochem. SOC. 133:496-500.

Peterson, R. D., 0.H. Koski, L. G. Morgan, N. E. Richards, D. M. Strachan, and A. T. Tabereaux. 1989. "Results of 100-Hour Electrolys is Test of a Cermet Anode: Operational Results and Industry Perspective." In Light Metals 1990. The Metallurgical Society, Warrendale, Pennsylvania.

Strachan, D. M., 0. H. Koski, L. G. Morgan, R. D. Peterson, N. E. Richards, A. T. Tabereaux, and R. E. Westerman. 1990. "Results from a 100-Hour Electrolysis Test of A Cermet Anode: Materials Aspects." In Light Metals 1990, The Metallurgical Society, Warrendale, Pennsylvania. 
APPENDIX 


\title{
ADVANCED SIGNAL ANALYSIS METHODS FOR ALUMINUM SMELTING DATA
}

\section{PRELIMINARY PROGRESS REPORT}

June 18, 1989 to September 30, 1989

\begin{abstract}
Submitted to:
Battelle

Pacific Northwest Laboratories

P.O. Box 999

Richland, Washington 99352

RE:

Subcontract No. 063117-A-F1

Prepared by:

Chrysostomos L. Nikias, Ph.D.

Principal Investigator
\end{abstract}

September 1989

A. 1 


\section{MATHEMATICAL METHODS}

In this section we briefly describe the DSA techniques that have been utilized to analyze the current and voltage signals. These are: Welch (FFT-based) method, Yule-Walker (YW) AR method, Magnitude-Squared Coherence (MSC), and nonlinear second-order Volterra modeling. Let $\{Y(1), Y(2), \ldots, Y(L)\}$ be the given set of data. Then we have the following:

1. Segment the data into $K$ records of $N$ samples each, i.e., $L=K N$.

2. Subtract the average value of each record (optional).

3. Assuming that $\left\{X_{i}(n), n=0,1, \ldots, N-1\right\}$ is the data set per segment $i=1,2, \ldots, K$, the Welch and YW spectrum estimation methods proceed as follows:

\section{A. Welch Method}

A.1 A window function $W(n)$ is used on each segment of data, i.e., $X_{i}(n)=X_{i}(n) \cdot W(n)$ where $W(n)$ is rectangular, Hamming or Hanning or any other window.

A.2 The periodogram spectrum is generated for each segment:

$$
P_{i}(l)=F F T\left[X_{i}(n)\right]
$$

and

$$
S_{i}(\ell)=\left|P_{i}(\ell)\right|^{2} \text { for } \ell=0,1, \ldots, \frac{N}{2}-1
$$

A.3 The Welch spectrum is obtained by averaging periodogram estimates:

$$
S_{W E}(\ell)=\frac{1}{K} \sum_{i=1}^{K} S_{i}(\ell)
$$

So, if $N=2048$, then $\ell=0,1, \ldots, 1023$ spectral components are generated uniformly from 0 $\mathrm{Hz}-(1 / 2 \mathrm{~T}) \mathrm{Hz}$ where $\mathrm{T}$ is the sampling period of the data. It has been well-established in the literature [2], [3], that the variance of the Welch spectrom is

$$
\operatorname{var}\left[S_{W E}(\ell)\right] \sim \frac{1}{K} S^{2}(\ell)
$$

where $S(\ell)$ is the true spectrum of the data and $\mathrm{K}$ the total number of segments. Thus, the larger is $K$, the smaller will be the variance in the spectrum estimate. 


\section{B. Yule-Walker (YW) Autoregressive Method}

The YW method (also known as maximum entropy metbod) is based on estimates of the autocorrelation sequence of the data. The YW method fits an AR model (IIR fiter with only poles) to the autocorrelation data by minimizing the variance of the linear prediction errors. This optimization problem results into a linear system of equations in which the matrix is Toeplitz and symmetric. The soiution of this linear system of equations is obtained by the Levinson recursion [2], [3].

The implementation of the YW method proceeds as follows:

B.1 The autocorrelation (AC) sequence is estimated at each segment:

$$
\begin{aligned}
R_{i}(m) & =\frac{1}{N} \sum_{n=0}^{N-1-m} X_{i}(n) X_{i}(n+m) \\
m & =0,1, \ldots, M .
\end{aligned}
$$

Note that $R(m)=R(-m)$.

B.2 The average $\mathrm{AC}$ sequence is obtained:

$$
\begin{aligned}
R(m) & =\frac{1}{K} \sum_{i=1}^{K} R_{i}(m) \\
m & =0,1, \ldots, M .
\end{aligned}
$$

B.3 The Levinson algorithm, described in Table $\mathrm{T}$ has as input the $\mathrm{AC}$ sequence $\{R(0), \ldots, R(M)\}$ and generates in the output the variance of the linear prediction errors $P_{M}$ and the $\mathrm{AR}$ model coefficients $\left\{a_{M}(1), a_{M}(2), \ldots, a_{M}(M)\right\}$. Table I also shows the AR model order selection criteria, namely FPE, AIC, CAT. [1], [2].

B.4 The resulting power spectrum is given by

$$
\begin{aligned}
S(f) & =T /\left|1+\sum_{i=1}^{M} \alpha_{m}(i) \exp j(2 \pi f i T)\right|^{2} \\
|f| & \leq 1 / 2 T
\end{aligned}
$$

where $T$ is the sampling period of the data

The YW method belongs to the class of high resolution spectrum estimation algorithms. The spectral variance of tbe YW method is significantly less than the Welch method, especially for short 
length data records. However, the seiection of the AR model order $M$ requires caution in order to avoid large bias in the YW spectrum estimate.

\section{Magnitude-Squared Coherence (MSC)}

The MSC is computed by utilizing tbe Welch method described above and two different sets of data, say $\{Y(1), \ldots, Y(L)\}$ and $\{Z(1), \ldots, Z(L)\}$. In particular, we have the folloning:

C.I Segment both data into $\mathrm{K}$ records of $\mathrm{N}$ samples each; i.e., $L=K \cdot N$.

C.2 Let us assume that $\left\{x_{i}(n), n=0,1, \ldots, N-1\right\}$ is the data set per segment of $\{Y(k)\}$ and that $\left\{w_{i}(n), n=0,1, \ldots, N-1\right\}$ the data set per segment of $\{Z(k)\}$, where $i=1,2, \ldots, K$.

C.3 The FFT operation is applied on each segment of data

$$
\begin{aligned}
& X_{i}(\ell)=F F T\left[x_{i}(n)\right], \\
& W_{i}(\ell)=F F T\left[w_{i}(n)\right], \quad i=1,2, \ldots, K
\end{aligned}
$$

and the auto- and cross-spectra generated; i.e.,

$$
\begin{aligned}
S_{x x}^{(i)}(\ell) & =\left|X_{i}(\ell)\right|^{2}, \\
S_{w w}^{(i)}(\ell) & =\left|W_{i}(\ell)\right|^{2}, \\
S_{x w}^{(i)}(\ell) & =X_{i}(\ell) \cdot W_{i}^{*}(\ell), \quad \ell=0,1, \ldots, \frac{N}{2}-1
\end{aligned}
$$

C.4 The Welch anto- and cross-spectra are obtained by averaging

$$
\begin{aligned}
& S_{x x}(\ell)=\frac{1}{K} \sum_{i=1}^{K} S_{x x}^{(i)}(\ell) \\
& S_{w w}(\ell)=\frac{1}{K} \sum_{i=1}^{K} S_{w w}^{(i)}(\ell) \\
& S_{x w}(\ell)=\frac{1}{K} \sum_{i=1}^{K} S_{x w}^{(i)}(\ell)
\end{aligned}
$$

C.5 The magnitude-squared coherenced is defined by

$$
\begin{gathered}
M S C(\ell)=\frac{\left|S_{x w}(\ell)\right|^{2}}{S_{x x}(\ell) \cdot S_{w w}(\ell)} \\
\ell=0,1, \ldots, \frac{N}{2}-1
\end{gathered}
$$


and is always $0 \leq M S C(\ell) \leq 1$ for all frequency values $\ell$.

\section{Nonlinear Volterra Modeling}

A simple second-order Volterra model consisting of linear and quadratic components with input $\{Z(k)\}$ and output $\{Y(k)\}$ is the following

$$
Y(k)=A_{1}+B_{1} Z(k)+C_{11} Z^{2}(k)+C_{12} Z(k) Z(k-1)+C_{22} Z^{2}(k-1)
$$

where $A_{1}$ is a dc value, $B_{1}$ is the linear component paramters and $\left\{C_{11}, C_{12}, C_{22}\right\}$ are the nonlinear quadratic component parameters. Let us note that if $\{Y(k)\}$ is current and $\{Z(k)\}$ is voltage, then $1 / B_{1}$ corresponds to resistance. The Volterra model parameters are estimated via singular value decomposition (SVD) as follows:

D.1 From the above basic model equation, we have the following relationship between higher-order statistics

$$
\begin{aligned}
R_{y z}(i)=m_{x} A_{1} & +R_{z z}(i) B_{1}+M_{z}(0, i) C_{11} \\
& +M_{x}(1, i) C_{12}+M_{z}(0, i-1) C_{22}
\end{aligned}
$$

for $i=0,1,2, \ldots, J$

where

$$
\begin{aligned}
R_{y x}(i) & =\sum_{k} Y(k) Z(k-i) & \text { (cross - correiations) } \\
m_{x} & =\sum_{k} Z(k) & \text { (mean) } \\
R_{x z}(i) & =\sum_{k} Z(k) Z(k-i) & \text { (auto - correlations) } \\
M_{z}(j, i) & =\sum_{k} Z(k) Z(k-j) Z(k-i) & \text { (3rd - order moments) }
\end{aligned}
$$

D.2 The following overdetermined system of equations may be so obtained.

$$
A x=\underline{b}
$$

where $\mathrm{A}$ is $(J+1) \times 5$ matrix of higher-order statistics, $\mathrm{x}=\left[A_{1}, B_{1}, C_{11}, C_{12}, C_{22}\right]^{T}$ and $\mathrm{b}=[R y z(o), \ldots, R y z(J)]^{T}$.

D.3 The SVD of A is [2]:

$$
A=\sum_{i=1}^{P} \sigma_{i} Y_{i} S_{i}^{H}
$$


TABLE I $Y$

THE LEVINSON ALGORITHM

$$
\begin{aligned}
& P_{0}=R(0) \\
& \lambda=1,2, \ldots, M \\
& a_{\lambda}(\lambda)=-\left\{R(\lambda)+\sum_{1=1}^{\lambda-1} a_{\lambda-1}(j) R(\lambda-1)\right\} / P_{\lambda-1} \\
& \rfloor=1,2, \ldots, \lambda-1 \\
& a_{\lambda}(j)=a_{\lambda-1}(j)+a_{\lambda}(\lambda) a_{\lambda-1}(\lambda-j) \\
& P_{\lambda}=\left(1-\left|a_{\lambda}(\lambda)\right|^{2}\right) P_{\lambda-1} \\
& \operatorname{FPE}(\lambda)=\frac{(N+\lambda)}{(N-\lambda)} \cdot P_{\lambda} \\
& \operatorname{AIC}(\lambda)-N \ln \left[P_{\lambda}\right]+2 \lambda \\
& Q_{\lambda}=\frac{N}{N-\lambda} \cdot P_{\lambda} \\
& \operatorname{CAI}(\lambda)=\left(\frac{1}{N} \sum_{1=1}^{\lambda} \frac{1}{a_{1}}\right)-\frac{1}{Q_{1}}
\end{aligned}
$$




$$
\sigma_{1} \geq \sigma_{2} \geq \ldots \geq \sigma_{\tau}
$$

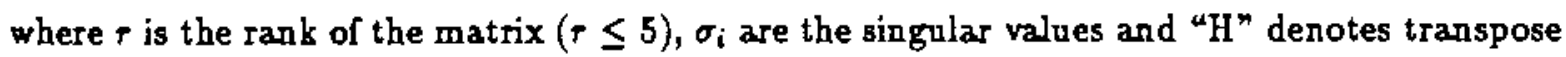
conjugate. The pseudo-inverse of the matrix $A$ is

$$
A^{+}=\sum_{i=1}^{r} \frac{1}{\sigma_{i}} S_{i} V_{i}^{H}
$$

D.4 The solution $\mathrm{x}$ via SVD is given by

$$
x=A^{+} b
$$

It is important to note that even if the matrix $A$ is full rank $(r=5)$, it can always be approximated by a lower rank matrix, $\dot{A}$, in the mean-square error (mse) sense as follows

$$
\dot{A}=\sum_{i=1}^{p} \sigma_{i} Y_{i} S_{i}^{H}
$$

where $p<r$.

\section{E. Quantification Parameters}

The set of ad-hoc quantification parameters that has been identified from these DSA methods is the following:

E.1 The total power of the signal (area under power spectrum).

E.2 The first-, second-, and third-order moment of the power spectral density, i.e.,

$$
M(n)=\int f^{n} S(f) d f \text { for } n=1,2,3
$$

E.3 The number and location of spectral peaks.

E.4 The number, location, and amplitude of MSC peaks.

E.5 The $P_{\lambda} / R(o)$ parameter computed by the Levinson algorithm (Table $\Gamma$ ) for orders $\lambda=$ 1,15 or 25 .

E.6 The Volterra model parameters $A_{1}, B_{1}, C_{11}, C_{12}, C_{22}$. 



\section{DISTRIBUTION}

No. of

Copies

OFFSITE

M. J. McMonigle

U.S. Department of Energy

Office of Industrial Programs

Forrestal Building

Washington, DC 20585

P. H. Salmon-Cox

U.S. Department of Energy

Office of Industrial Programs

Forrestal Building

Washington, DC 20585

12 DOE Office of Scientific and Technical Information

C. Anderson

Columbia Aluminum Co.

85 John Day Dam Road

Goldendale, WA 98620

J. V. Anderson

WCVE3

EG\&G Idaho, Inc.

Idaho Falls, ID 83415

D. Auburg

Bonneville Power Administration

P.0. Box 3621, PDX 97208

Portland, OR 97208

F. W. Baker

Ceramics Division

Alcoa Laboratories

Alcoa Center, PA 15069

M. Baltzel1

Eastalco Aluminum Company

Alumax, Inc.

5601 Manor Woods

Frederick, MD 21701
No. of

Copies

J. A. Barclay

U.S. Bureau of Mines

2401 "E" Street N.W.

Washington, DC 20241

H. Robert Baumgartner

Ceramics Division

Alcoa Laboratories

Alcoa Center, PA 15069

T. R. Beck

Electrochemical Technology Corp.

1601 Dexter Avenue

Seattle, WA 98109

S. Berwagan

Bonneville Power Administration

P.0. Box $3621 \mathrm{~K}$

Portland, OR 97208

T. M. Besmann

Metals and Ceramics Division

Oak Ridge National Laboratory

P.0. Box X, Bldg. 4515

Oak Ridge, IN 37831-6063

K. A. Blakely

President

Advanced Refractory

Technologies, Inc.

699 Hertel Ave.

Buffalo, NY 14207

M. H. Blenk

Du Pont

P.0. Box 787

Niagara Falls, NY 14302 
No. of

Copies

L. G. Boxall

Martin Marietta Laboratories

1450 South Rolling

Baltimore, MD 21227

J. Bracher

Kaiser Aluminum and Chemical Corp.

825 N.E. Multnomah St., Suite 960

Portland, OR 97232-2150

R. Brandt

Department of Materials Science and Engineering

University of Washington FB-10

Seattle, WA 98195

J. J. Brown, Jr.

Materials Engineering

Virginia Polytechnic Institute

Blacksburg, VA 24061

A. Budner

Bonneville Power Administration

P.0. Box 3621--EPA

Portland, OR 97208

A. J. Caputo

Metals and Ceramics Division

Oak Ridge National Laboratory

P.0. Box X

0ak Ridge, TN 37831-6063

N. Clark

Bonneville Power AdministrationIndustrial Conservation

P.0. Box 3621

Portland, OR 97208

A. Cooke

Martin Marietta Laboratories

1450 South Rolling

Baltimore, MO 21227
No. of

Copies

J. A. Coppola

Standard $0 i 1$ Engineered

Materials Company

P.0. Box 156

Niagara Falls, NY 14302

D. D. Cudaback

Director

Washington State Dept of Trade and Economic Development

312 First Avenue North

Seattle, WA 98109

R. Curtis

Materials Development

Corporation

81 Hicks Avenue

Medford, MA 02155

J. V. Day

Kaiser Aluminum and Chemical Corp

E2111 Hawthorne Road

Mead, WA 99021

R. Dethlefsen

Maxwe 11 Laboratories

8888 Balboa Ave

San Diego, CA 92123

D. H. DeYoung

Alcoa Technical Center

Alcoa Center, PA 15069

S. Di amond

Battelle Columbus Laboratories

505 King Avenue

Columbus, $\mathrm{OH}$ 43201-2693

C. W. Doerr

The Stackpole Corporation

Cermag Division

201 Stackpole Street

St. Marys, PA 15847 
No. of

Copies

T. Dwonch

Snake River District

BPA

101 W. Poplar

Walla Walla, WA 99362

G. L. Eitel

Stone \& Webster Engineering Corp.

Greenwood Plaza Box 5406

Denver, CO 80217

R. Engdahl

Deposits and Composites, Inc.

318 Victory Drive

Herndon, VA 22070

J. F. Elliott

MIT

Room 4-138

77 Massachusetts Avenue

Cambridge, MA 02139

B. G. Epstein

A. D. Little, Inc.

955 Lenfant Plaza SW 4200

Washington, DC 20024-2119

J. W. Evans

University of California

Dept of Mat1. Sci. and Minerai Eng.

Berkeley, CA 94720

R. A. Fenimore

ICI Advanced Materials

Rollins Building, Eighth Floor

Wilmington, DE 19897

D. A. Figgins

ARCO Petroleum Products Co.

P.0. Box 61004

Anaheim, CA 92803-6104
No. of

Copies

P. Foster

ATcoa Laboratories

P.0. Box 772

New Kinsington, PA 15068

J. Gee

Great Lakes Research Corp

P.0. Box 1031

Elizabethton, TN 37643

T. Gilligan

Eltech Systems Corp.

625 East Street

Fairport Harbor, $\mathrm{OH} 44077$

W. M. Goldberger

Superior Graphite Co.

$120 \mathrm{~S}$. Riverside Plaza

Chicago, IL 60606

J. Goodwell

Center for Metals Production

Mellon Institute

4400 Fifth Avenue

Pittsburgh, PA 15213

J.A.S. Green

Martin Marietta Laboratories

1450 South Rolling

Baltimore, MD 21227

C. Griffin

Ceramatec Inc.

2425 S. 900 West

Salt Lake City, UT 84119

L. I. Grindstaff

Great Lakes Research Corp.

P.0. Box 1031

Elizabethon, TN 37643

J. Haggerty

MIT

Building 12, Room 009

77 Massachusetts Avenue

Cambridge, MA 02139 
No. of

Copies

I. L. Harry

Electric Power Research. Institute

P.0. Box 10412

Palo Alto, CA 94303

W. E. Haupin

2820 7th Street Road

Lower Burre11, PA 15068

R. Hill

Union Carbide Corp.

P.0. Box 94637

Cleveland, $\mathrm{OH} 44101$

H. F. Hillegass

Alcoa Wenatchee Works

P.0. Box 221

Wenatchee, WA 98807

D. G. Howitt

College of Engineering

University of California, Davis

Davis, CA 95616

F. R. Huettig

Advanced Magnetics, Inc.

45 Corey Lane

Mendham, NJ 07945

G. R. Hyde

U.S. Bureau of Mines

2401 "E" Street N.W.

Washington, DC 20241

S. C. Jacobs

Primary Processing

Aluminum Company of America

Alcoa Technical Center

Alcoa Center, PA 15069

S. H. Jan

Tennessee Valley Authority

1850 Commerce Union Bank Bldg.

Chattanooga, TN 37401
No. of

Copies

\author{
N. Jarrett \\ 149 Jefferson Avenue \\ New Kinsington, PA 15068 \\ J. Johnson \\ Intalco Aluminum Company \\ P.0. Box 937 \\ Ferndale, WA 98248 \\ M. H. Johnson \\ Alcoa Wenatchee Works \\ P.0. Box 221 \\ Wenatchee, WA 98801 \\ L. Joo \\ Great Lakes Research Corp \\ P.0. Box 1031 \\ Elizabethon, TN 37643
}

M. Karmous

Oregon State Department of Energy

625 Marion Street, N.E.

Salem, OR 97310

R. Keller

RD 3 Roundtop Road

Export, PA 15632

K. Krupinski

Mail Stop 57

U.S. Steel Technical Center

1 Technical Center Drive

Monroeville, PA 15146

G. Y. Lai

Cabot Corporation

P.0. Box 9013

Kokomo, IN 46902-9013

R. A. Landy

Director of Research

North American Refractories Co. 3127 Research Dr.

State College, PA 16801 
No. of

Copies

J. E. Lane

Ceramic Research and Development Center

Westinghouse Electric Corporation

1310 Beulah Road

Pittsburgh, PA 15235

Sai-Kwing Lau

Standard 0iT Engineered

Materials Company

Niagara Falls R\&D Center

P.0. Box 832

Niagara Falls, NY 14302

J. J. Leddy

Dow Chemical U.S.A.

1776 Building

Midland, MI 48640

W. W. Liang

Gas Research Institute

8600 West Bryne Mawr Avenue

Chicago, IL 60631

W. H. Link

Columbia Aluminum Corp.

85 John Day Dam Road

Goldenda Te, WA 98620

Steve Loftness

Washington State Energy Office

400 E. Union

O1ympia, WA 98504

W. Long

Building B815

Dow Chemical

Freeport, Texas 77541

A. G. Longmuir

Kaiser Aluminum and Chemical Corp.

P.0. Box 877

Pleasonton, CA 94566
No. of

Copies

R. A. Lowden

Metals and Ceramics Division

Oak Ridge National Laboratory

P.O. Box X, Bldg, 4515

0ak Ridge, TN 37831-6063

W. N. Maclay

Koppers Company, Inc.

440 College Park Drive

Monroeville, PA 15146

J. C. McCloskey

Ten Mile River Associates

$296 \mathrm{Mt}$. Hope Street

North Attleboro, MA 02760

S. C. Manaktala

Manager of Technology

Reduction Division

Kajser Aluminum and Chemical Corp

300 Lakeside Drive

Oakland, CA 94643

V. H. Markant

Du Pont

P.0. Box 787

Niagara Falis, NY 14302

C. J. McMinn

Extractive Metallurgical Department

Reynolds Metals Company

P.0. Box 1200

Sheffield, AL 35660

C. H. McMurtry

Standard 0il Engineered

Materials Company

Niagara Falls R\&D Center

P.0. Box 832

Niagara Falis, NY 14302

M. A. Mitnick

Avco Specialty Materials

Subsidiary of Textron Inc.

2 Industrial Avenue

Lowe 11, MA 01851 
No. of

Copies

H. Mortensen

R. Palika

Cercom, Inc.

P.0. Box 70

Vista, CA 92083

A. Moussa

A. D. Little, Inc.

20 Acorn Park

Cambridge, MA 02140

B. C. Mutsuddy

Battelle Columbus Division

505 King Avenue

Columbus, $\mathrm{OH}$ 43201-2693

P. Ness

Senior Project Manager

Washington State Dept of Trade and Economic Development

312 First Avenue North

Seattle, WA 98109

A. N. Pate 1

Battelle Columbus Laboratories

$505 \mathrm{King}$ Avenue

Columbus, OH 43201-2693

J. R. Payne

Kaiser Aluminum and Chemical Corp.

P.0. Box 877

Pleasanton, CA 94566

T. Payne

Columbia Falls Aluminum Co.

Columbia Falls, MT

W. Pebley

Oregon Freeze Dry Corp.

525 25th Avenue SW

P.0. Box 1048

Albany, OR 97321
No. of

Copies

K. Peterson

Columbia Aluminum Corp.

85 John Day Dam Road

Goldendale, WA 98620

R. D. Peterson

Reynolds Metals Company

P.0. Box 1200

Sheffield, AL 35660

T. R. Pritchett

Kajser Aluminum and Chemical Corp.

P.0. Box 877

W. W. Pritsky

Aluminum Association

900 19th St. N.W.

Washington, DC 20006

S. P. Ray

Alcoa Technical Center

Alcoa Center, PA 15069

J. F. Rhodes

Advanced Composite Materials Corp.

1525 S. Buncomb Rd. Greer, SC 29651

N. E. Richards

Reduction Laboratory

Reynolds Aluminum Corporation P.0. Box 1200

Sheffield, AL 35660

J. J. Ritter

Ceramics Division

National Bureau of Standards

Gaithersburg, MD 20899

R. C. Rohwedder

3028 Ohio Street

Longriew, WA 
No. of

Copies

J. Rosling

Myers Metals and Minerals

459 Colman Building

Seattle, WA 98104

D. R. Sadoway

MIT

Room 8-109

77 Massachusetts Avenue

Cambridge, MA 02139

W. Scott

Department of Materials Science \& Engineering

Wilcox Hall FB-10

University of Washington

Seattle, WA 98195

D. R. Secrist

Great Lakes Research Corp.

P.0. Box 103I

Elizabethon, TN 37643

A. B. Shah

Noranda Aluminum, Inc.

P.0. Box 70

New Madras, MO 63869

N. Shelton

IntaTco

1300 S. W. 5th, Suite 3508

Portland, OR 97201

F. W. Spillers

Dow Chemical U.S.A.

B-1210 Building

Freeport, TX 77541

Dr. Richard M. Spriggs

Office of the Director

Center for Advanced

Ceramic Technology

Alfred University

A]fred, NY 14802
No. of

Copies

D. V. Stewart

Reynolds Metals Co.

P.0. Box 1200

Sheffield, AL 35660

D. Strahan

Reynolds Metals Company

P.0. Box 27003

Richmond, VA 23261

A. T. Tabereaux

Reynolds Metals Company

P.0. Box 1200

Sheffield, AL 35660

G. P. Tarcy

Aluminum Company of America

Alcoa Technical Center

Alcoa Center, PA 15069

P. Thaure

Primary Planning and Production

Alumax

400 S. El Camino Rd.

San Mateo, CA 94402

W. H. Thielbahr

Conservative Technology

Division

DOE-Idaho Operations office

785 DOE Place

Idaho Falls, ID 83402

S. Thomson

General Manager

Klickitat PUD

$1313 \mathrm{~S}$. Columbus

Goldendale, WA 98620

R. Unger

Merner Research

P.O. Box 248

Ridgewood, NJ 07451 
No. of

Copies

A. Vinnard

Bonneville Power Administration (KWI)

P.0. Box 3621

Portland, OR 97208

T. Von Muller-KWI

Bonneville Power Administration

P.0. Box 3621

Portland, OR 97208

D. H. Weinblatt

AIMCOR

One Parkway North

Deerfield, IL 60015

J. D. Weyand

EG\&G Idaho, Inc.

Idaho Falls, ID 83415

B. Wilcox

Northwest Aluminum Co.

$3313 \mathrm{~W}$. Second St.

The Dalles, OR 97058

C. B. Wilson

Dow Chemical U.S. A.

Texas Operations

B-101 Building

Freeport, TX 77541

J. C. Withers

Keramont Research Corporation

$4233 \mathrm{~S}$. Fremont Avenue

Tucson, AZ 85714

W. A. Zdaniewski

Engelhard Corporation

Men lo Park, CN 28

Edison, NJ 08818

FOREIGN

D. Brodie

Comalco Ltd.

55 Collins St.

Melbourne, AUSTRALIA
No. of

Copies

\author{
H. Connor \\ Group Licensing Controller \\ Johnson Matthey, plc \\ New Garden House \\ 78 Hatton Garden \\ London EC1N 8JP ENGLAND
}

L. Dion

Alcan International Limited

C.P. 6090

Montreal, Quebec

CANADA, $\mathrm{H} 3 \mathrm{C} 3 \mathrm{H} 2$

T. Kjar

Comalco Ltd.

55 collins st.

Melbourne, AUSTRALIA

E. W. Dewing

Alcan International

P.0. Box 8400

Kingston, Ontario

CANADA K7L $4 Z 4$

[1. N. MacMillan

Alcan International

C.P. 1250

Jonquieve, Quebec

CANADA G7S $4 \mathrm{~KB}$

J. H. Reimers

Jan H. Reimers and Associates

Inc.

221 Lakeshore Road East

Oakville, Ontario

CANADA, L6J $1 \mathrm{H} 7$

A. Oye

Institute of Inorganic Chemistry

Norwegian Institute of Technology

University of Trondheim

N-7034 Trondheim-NTH, NORWAY 
No. of

Copies

J. Thonstad

Laboratories of Industrial Electrochemistry

Norwegian Institute of Technology

University of Trondheim

N-7034 Trondheim-NTH, NORWAY

K. 0. Vee

ASV Ardal Verk

N-5875 Ardalstargen, NORWAY

ONSITE

R. B. Goranson
No. of

Copies

25 Pacific Northwest Laboratory

M. Clement

N. C. Davis

D. K. Hilliard

G. L. McVay

N. L. Moore

L. G. Morgan (10)

C. H. Schilling

D. M. Strachan

R. E. Westerman

C. F. Windisch

Publishing Coordination

Technical Report Files (5) 


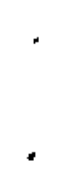

, 